1 方位み地基声地比驅地走第

は圆ら圖邦探地の就る質る息

資にずをにる質比てる時の紀

料印溯描於可調ではの代は時

未刷てかてき查な未でに其代

第を゙前れ第は所いだあ於丙に

吾不ら寒て言探發。調り汗で於

十充れ武居紀用行斯查ま年主

年分縮 紀りのし子くの专海々る

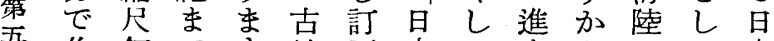

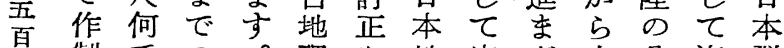

九製千の。理を地定ざ之分海群

十七萬各併荋要質說るが佈陸島

四得分紀しを鑛を處未はのの

號店之のこ作る産得多解海分古

管一古れり所誌る 決成佈地

第 狀と地は上は怘をあで廨の理

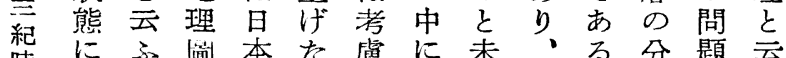

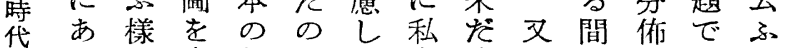

にるな畫版はて自遠箅はにあ演

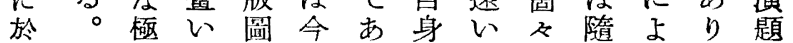

け此めて全回るがの攻てりまを

る處て居部最の記でび古て鸾揭

早に大りに初は逝あ一地制。げ

本揭雜まはと云しる般理斷海て

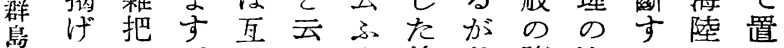

のたの。つふ汽第此諸海るのき

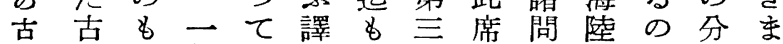

地地 の般居であ系で題ので扸し

理理がにりはり地本に分!論た

喟普古まなま展邦就佈游はが

女通地せ、せ第て 就古古

縮で理ぬ。ん對焉名不廨地地

尺あ訚。譬。比紀衆確の理理

三りは軖古古定對ので

百、歐》ばあ地一な比內取

莴詳洲?大楮致る更でり

分細々を塚ま論せをびも扱

一のか、學しのず挽其重ふ

で海・Q上

は陸北范は

あ分米兽第

る作と溥紀

詳は、士中

細 歌 亞はの

で洲 細 東 或

あは亞亞る

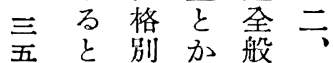

五 云别か般

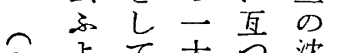

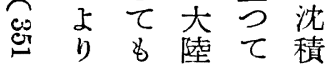

は其学第時

講 他一兰代

演 の頁紀 の

七基屡れ地要 放

勿礎々な質なの

論 $と$ 異

其し論。代部內

後たの日の門に

のる起本問とは

調第るの題な色

查严こ第郎つ々

复と菜的の

は の他系愿居部

發層のの位り門

表位中各論委加

理

神住

第誌

三 第

紀五

照

$\stackrel{+}{\equiv}$

吾

㝵

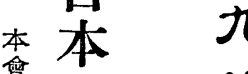

群㣛

會

島

の

古㕷

地

理

博

昭

士

和

渡

†

奉

邉

月

$+$

五

曰

ら類生 統 がす 基。

登

れ體や時礎、吉

$\bar{j} \bar{T}$

た系古代と此

論 は生涗昭代びり 席

に和 の 對 先

申 


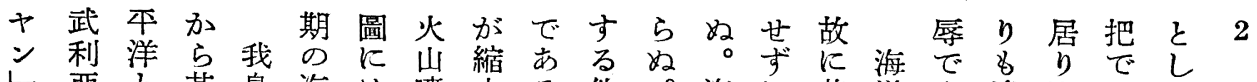

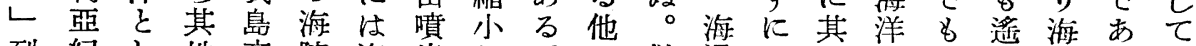

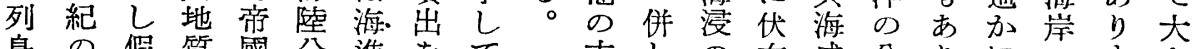
島の假質國分進をて

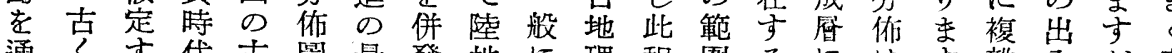

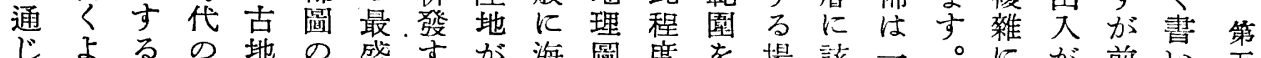
じよるの地の留すが海圆度を場該—。にが前い五 北太り經理作期る援浸がを決合當に是な甚逝た十

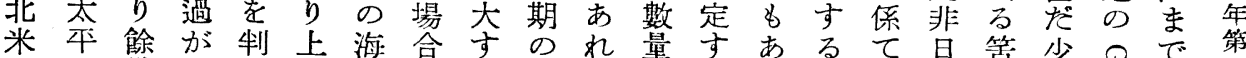

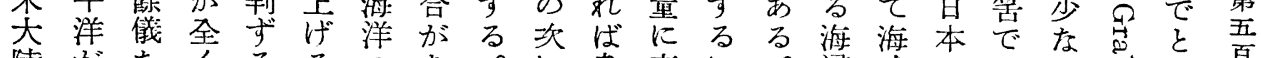
陸がなくるるのあ。に參表に。浸成の南い:

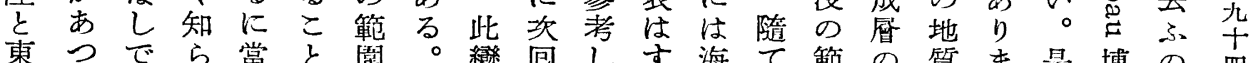

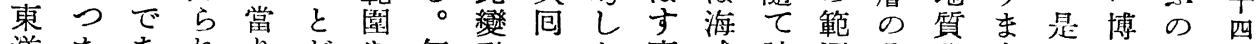

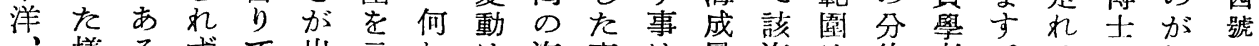
樣るずて出示れは海事は居海は佈者。はの面

東にが隨最來しの所浸は不の成海に自日古相

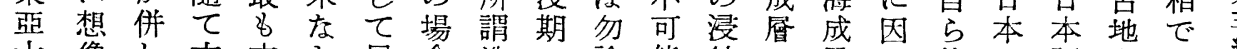

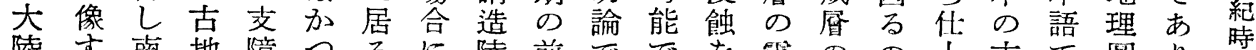

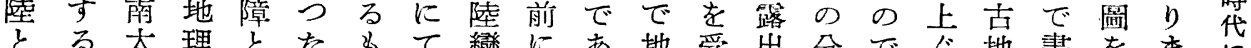

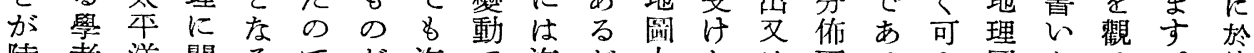

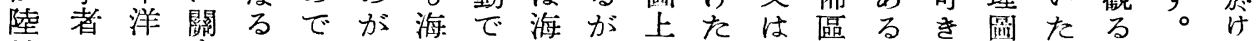
地がに势悉多退あ退其に程賦域が方を澤を雜る 相相はるのくくのる期凟表度存よ海の外山第誌早

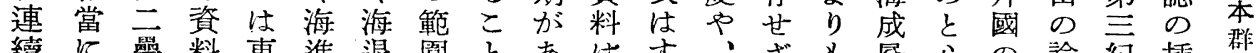

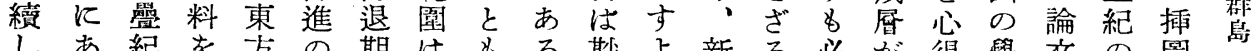

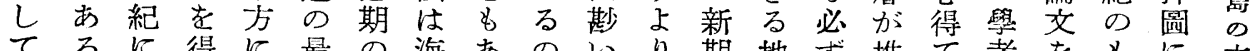
てるに得に最の海あのいり期地ず堆て者をるに古

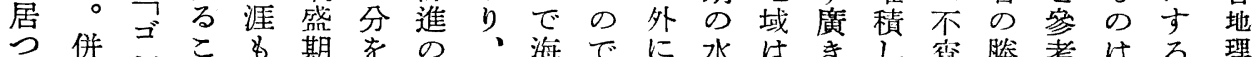

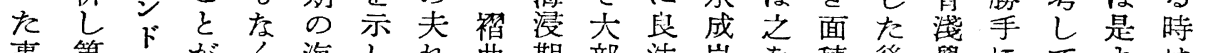
事第口汃海しれ曲期部法岩壳皘後學にてをは が言ナ出廣陸てょや飞分は愿直を其を作居り二

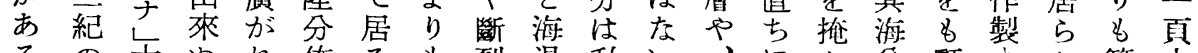

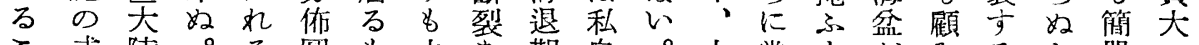

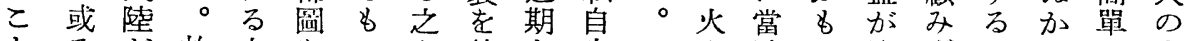

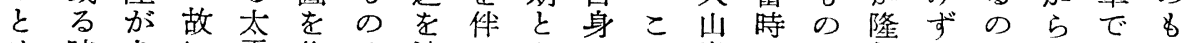
は時あに平作は追つを学あ岩ので起之にであの 兩代つ止洋製稀跡た交制が等陸あし省委あり、に 大にたすでしです造页斷郎に地るて試せり、縮 陸はこなあたあるあすすに古被郎。陸みてま日岡

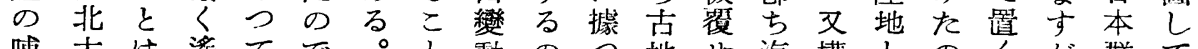
梀太は滛てで。と動のつ地せ海構とのくが群て

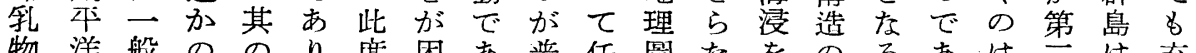

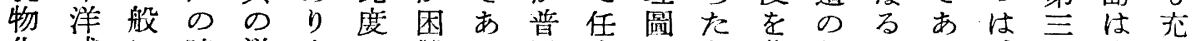
化或に時洋まの難る邂意に部蒙如やり誠紀大分 石は認代底す場でこでに成分ら何浸委に時抵に

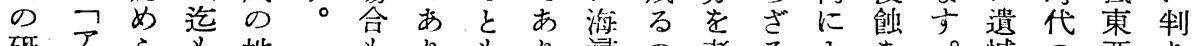

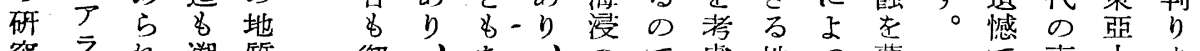

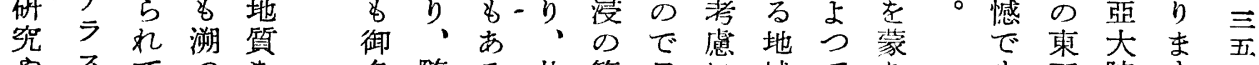
队

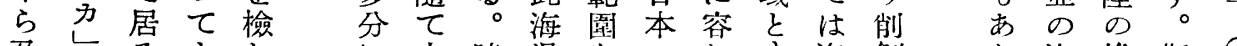

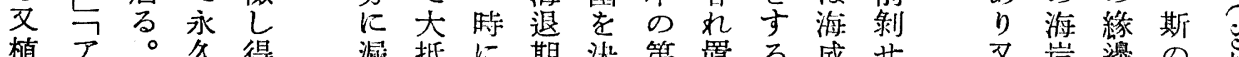

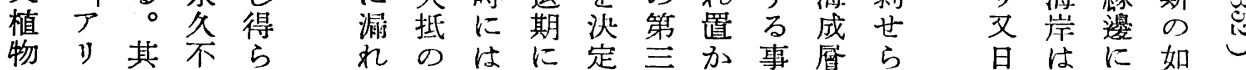

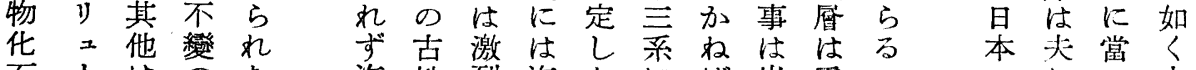

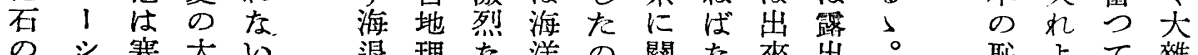
のシ寒太い退理な洋の關な來出。恥よて雜 

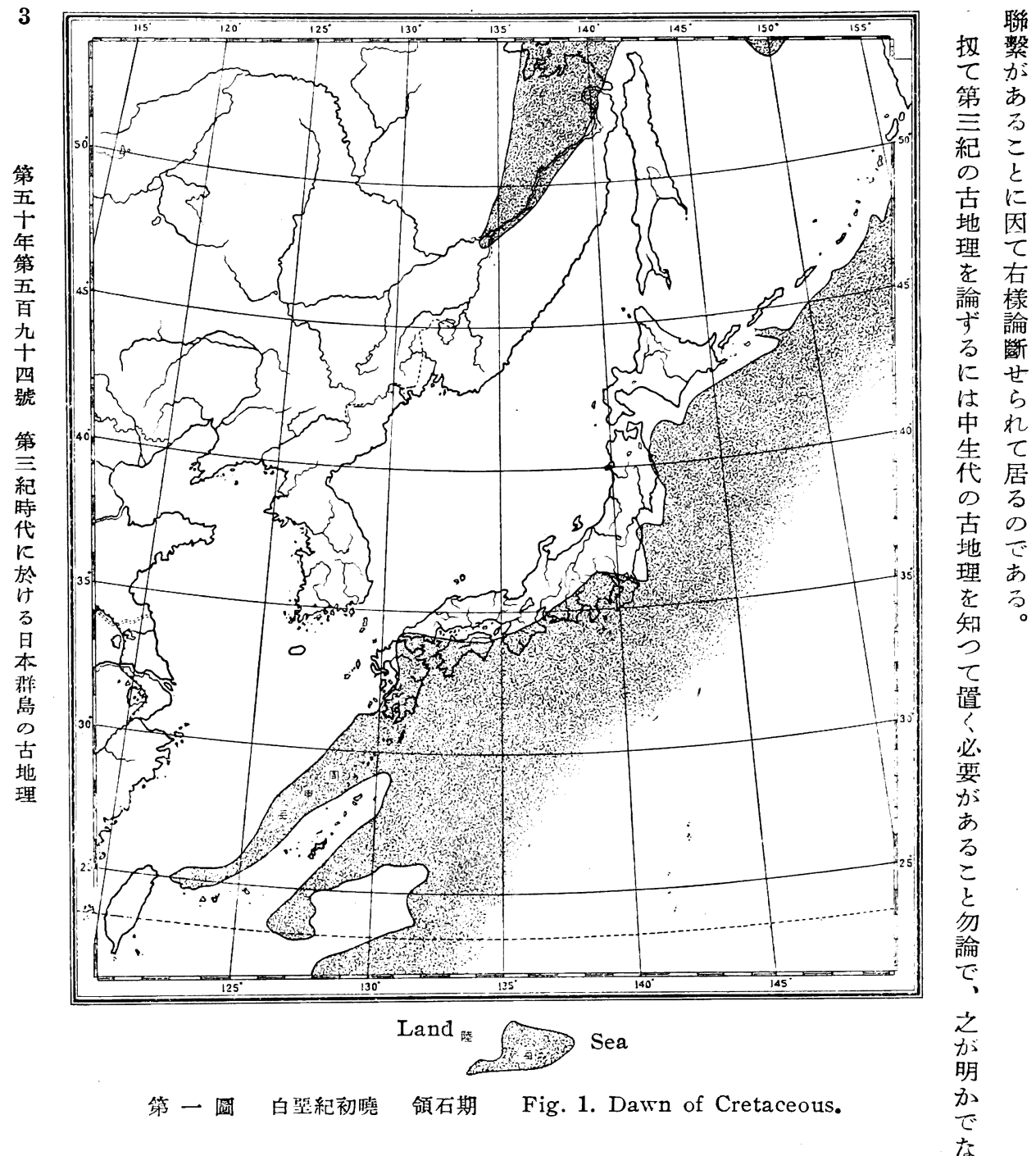

あ地時動がる底のちし海た模吾對生て理るい る理代に大と盤初恐志陸し、罢國し 代置にことと 以考ら 泥あ 容よ に 三下究振 せつしつ我珠は大生が 中 が地が古出紀 五第しりずたたて國羅㽞飛代あ生薄理便生來の

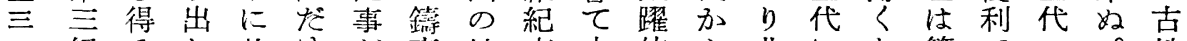
紀るし此けが直地末中的ら非にな第での。地 心古とて花失あさ體少代に變常花つ第古中理

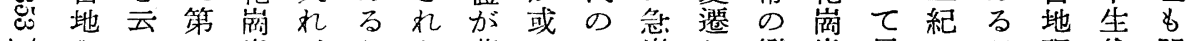

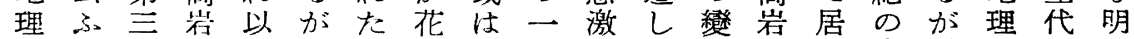
を便紀大前此程崫白時に來動のりり夫併をのか

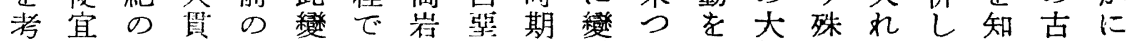

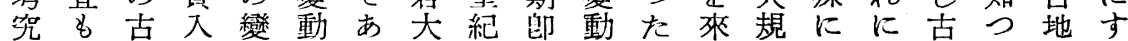




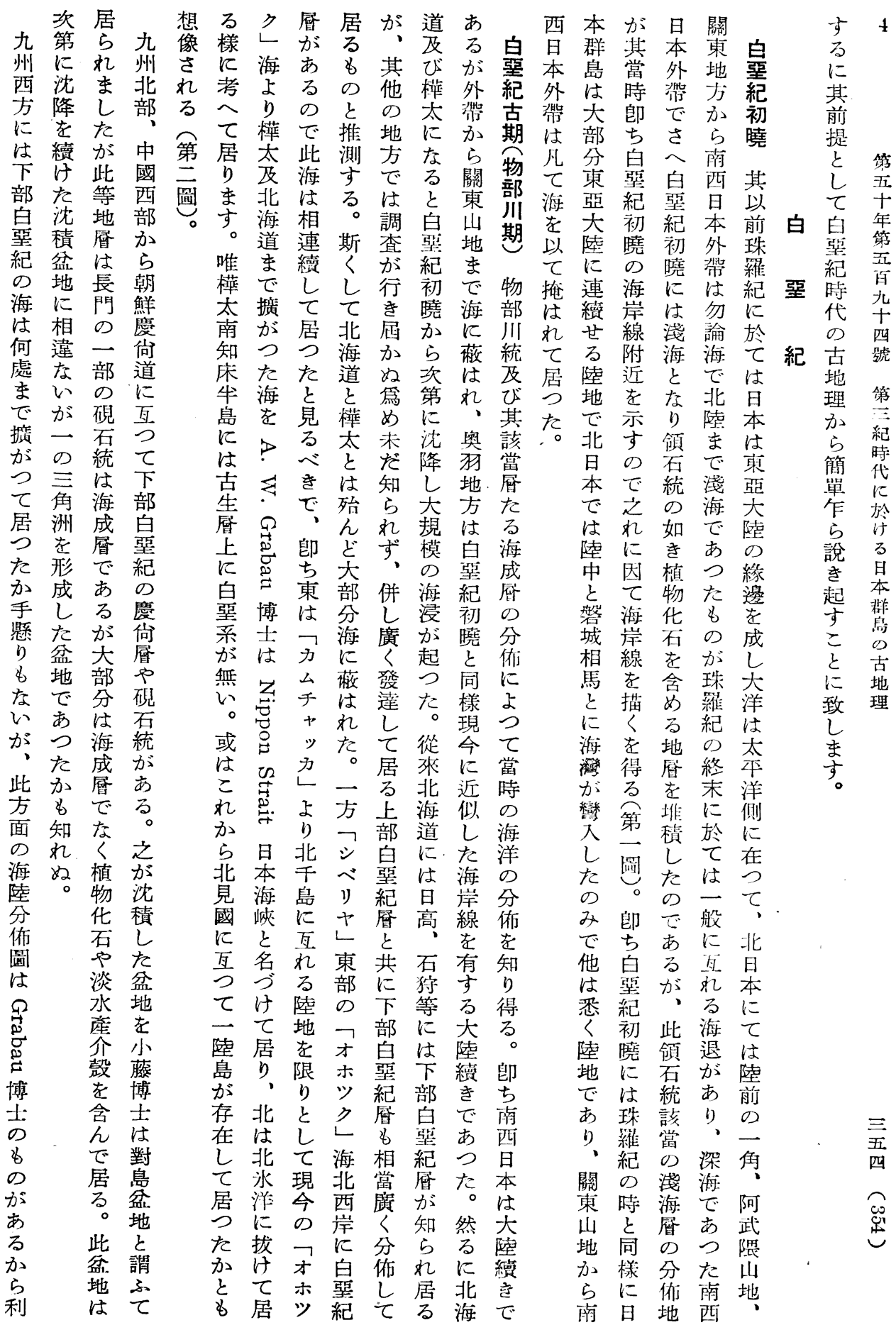




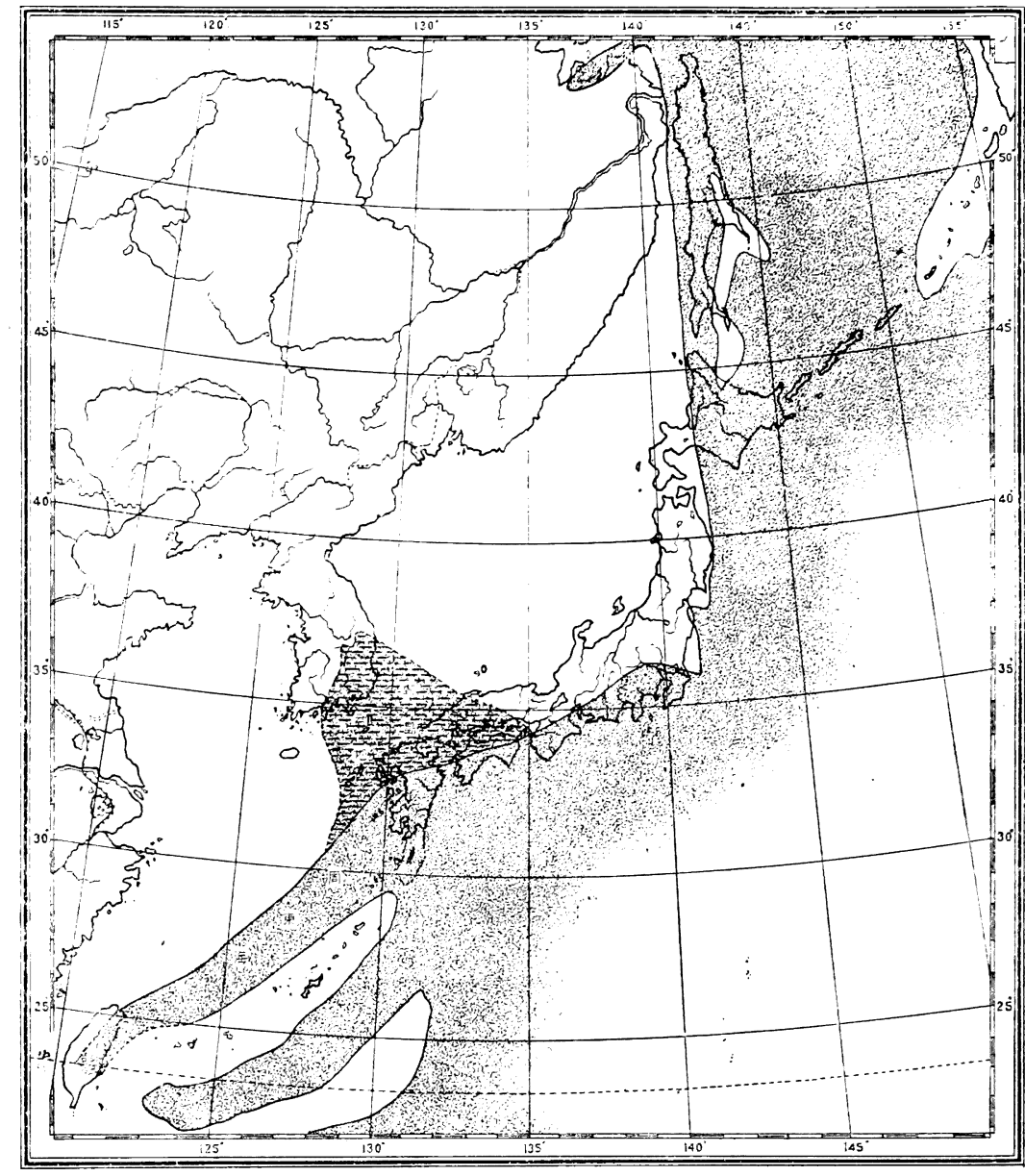

謂 却

䋓

介居

砂 つ

岩た

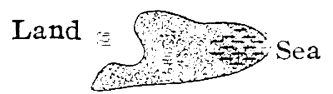

第二 四白恶紀古期 物部川期 Fig. 2. Early Cretaceous.

麻の

やで因石定

\section{港海で籍命こ侧定で含灣大@系用}

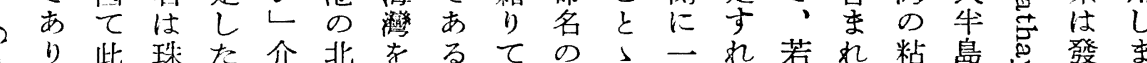

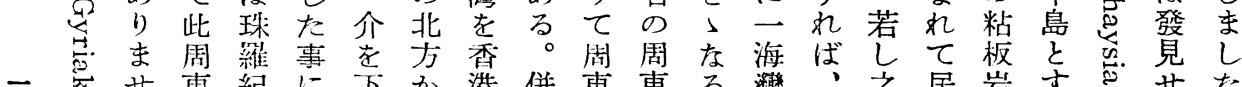

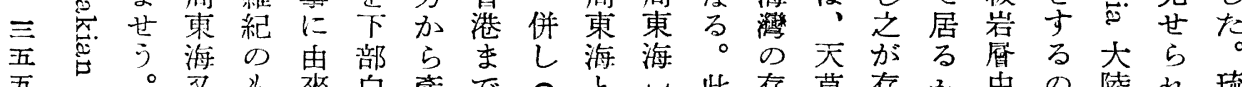

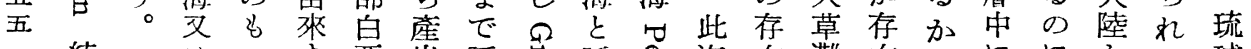

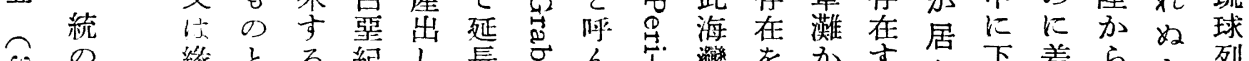

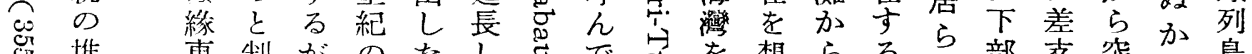

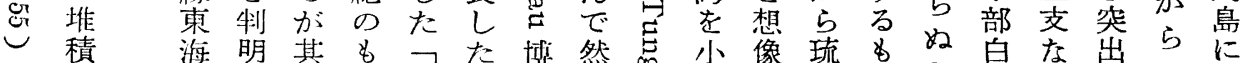

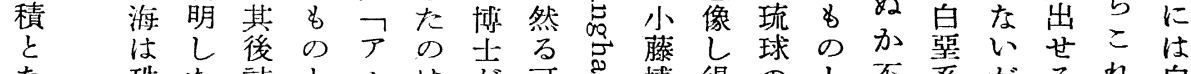

な珠た該とムは志可导博得のと不菜がるれ白

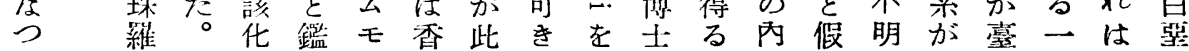




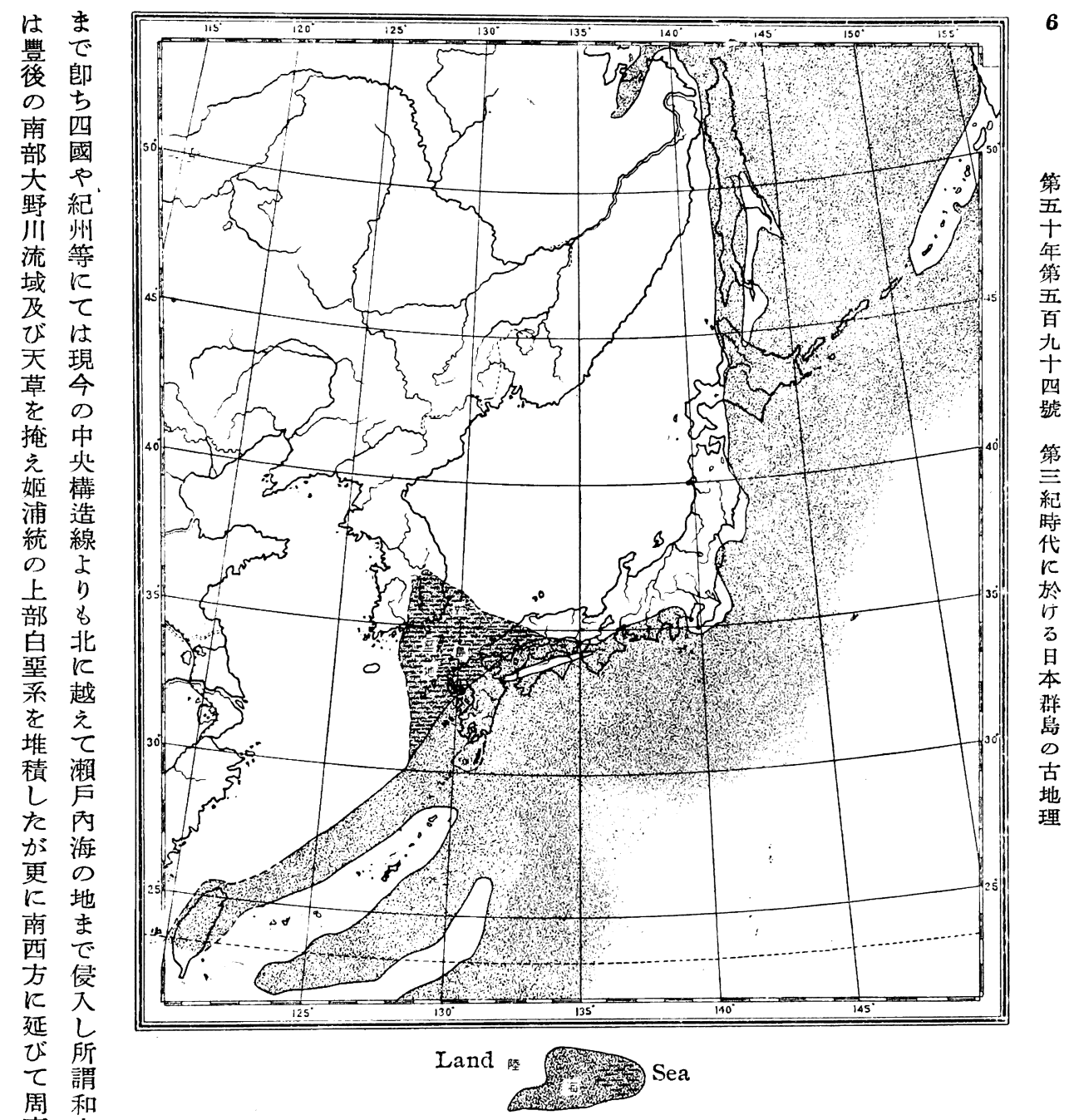

東 泉

海 砂

は岩

第三圆 白琵紀新期 浦河期 Fig. 3. Late Cretaceous.

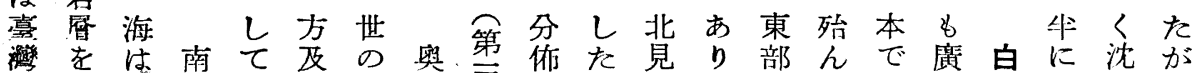

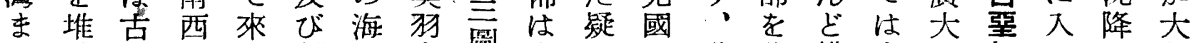

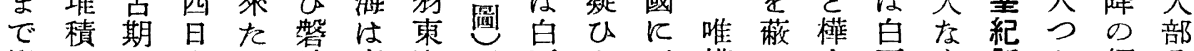

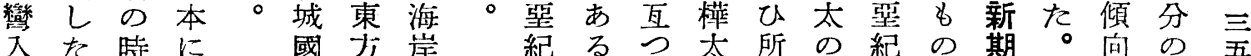
乙 た

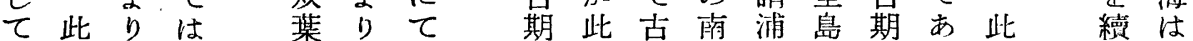

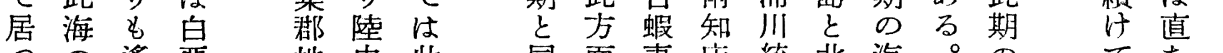

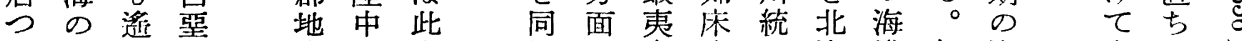
た西加紀方國白 樣は臭牛の海進郎海的に

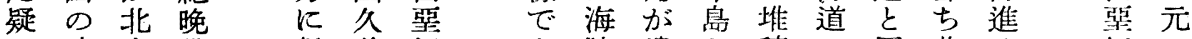
ひ連汸世信慈紀 あ陸遺吕積の同北は 紀の

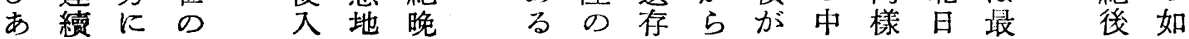




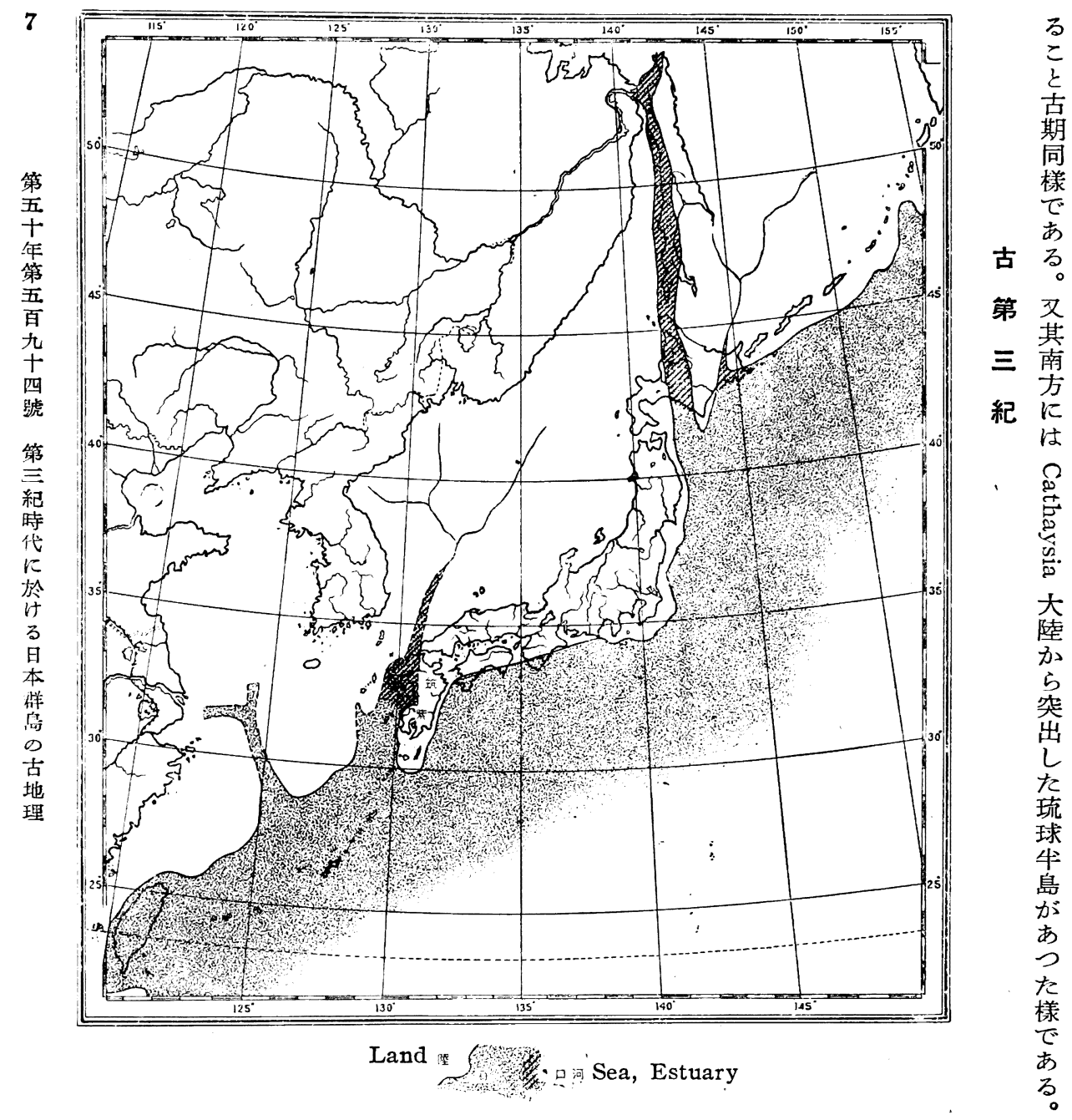

第四圆 始 新世 Fig. 4. Eocene.

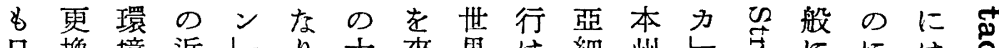

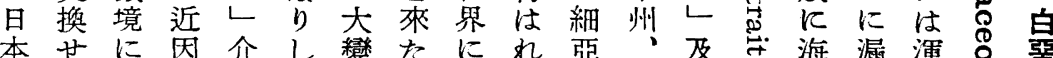

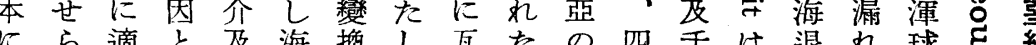

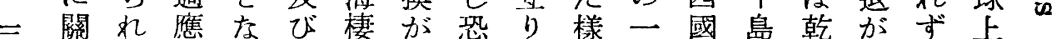
五すをせり网軟起ら海で部、まま涸起日全白

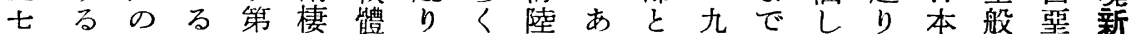

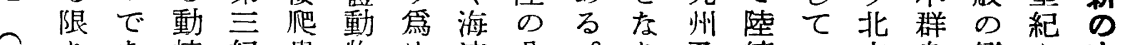

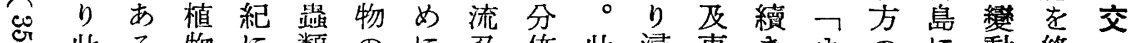
此る物に類のに爻佈此浸東き力のに動終

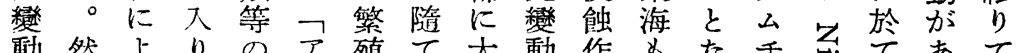

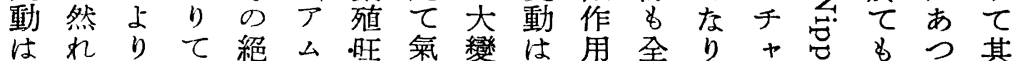
烈に゙て 新隇モ盛候化全が部、、ッ合全た後 


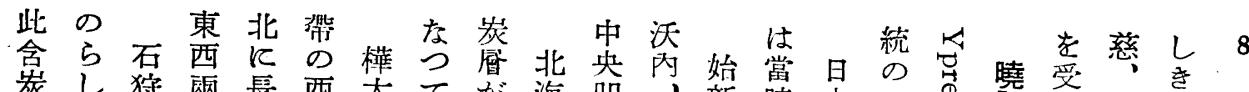

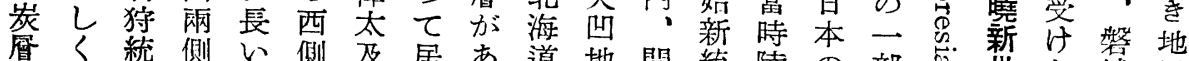

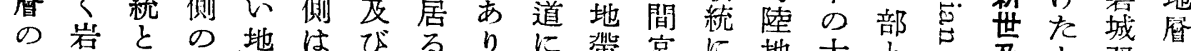

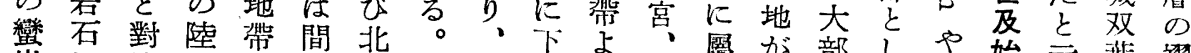
岩に比地に宮海石つ方專凰が部しや始云藮褶

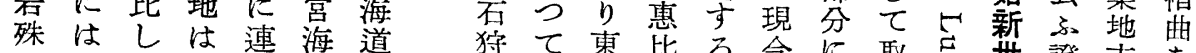
に石得高續峽の統同方須地今古取芯世證方を五

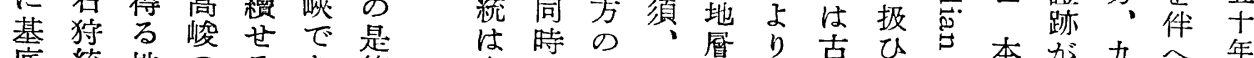

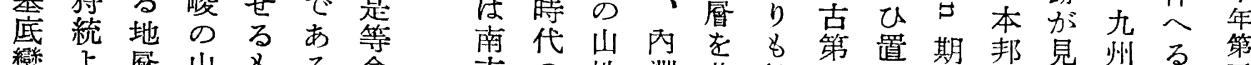
戀

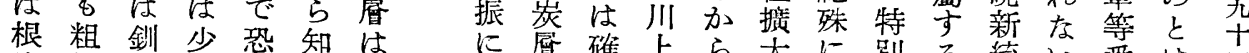

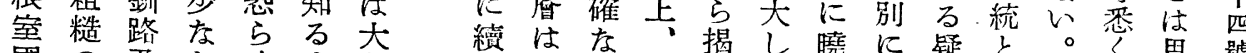

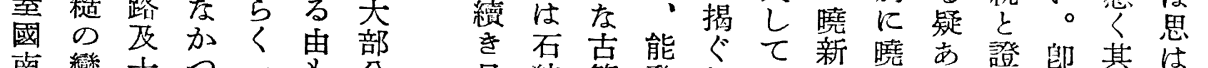

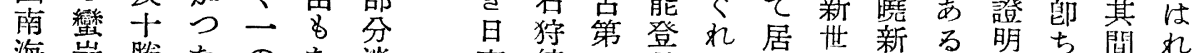
海岩勝たのな淡 岸䒽と河以水 に角國思口が成 點變には沈北層 飞岩浦れ皘海它 相加㹸る愿道牛 連發含。四の匏 な達䆜己恐中水

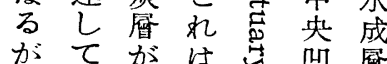
がてがは苔四愿

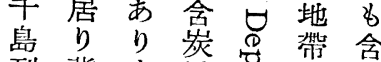
列背玉蟹宫 島後守息西れ に郎。岩でにる はち是石ははが 知十はにあ此純 ら勝太粗 る 含 然 れ國平鈢要炭 ての洋のい唇る 哭方岸繁かは海 いにの岩。店成

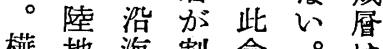
㩰地海制含。注 太染低合炭想含 の當箲に愿像ま 東時地少の守れ 牛存に量堆るて 部在かで積にな かし或あの權 い らてはる起太樣 北在別かつ质无 海つ箅らたびあ 道た樣河あ怔北る の 山溯沈 に得樍 突念で

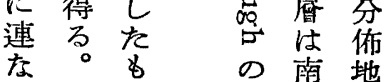
高統高ばつ及世呄せ白のな

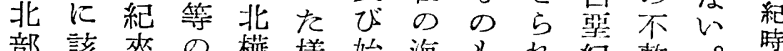
部該夾品權樣始海多れ紀整。時

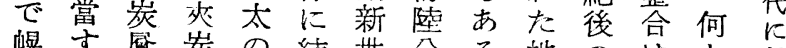
丙るは厤口結世分る地のはを 於 統北知はマし海圆極は勳蝕れる

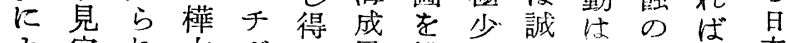
よ宗れ太ガら底描部に廣遗上本 己谷て の ての居中几さ少出あ心なが白島

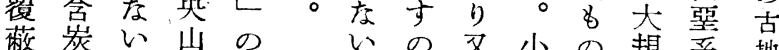
せ㕍。系含 の管及模系地

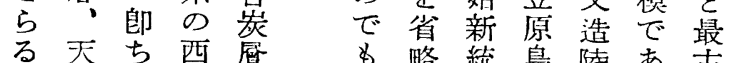
的略統島陸あ古 が幙菲贺同解し市鼓的るの

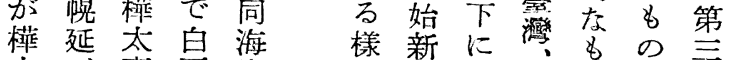
太東堅岸に世位琉のが柔 同筑牛系の海のし球であと 樣别部上、進海て或あつ兄

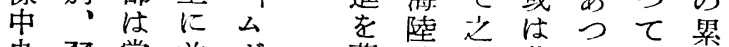
央雅賞亚芜分に北た\&重

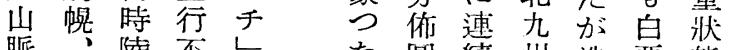
脈、陸不々た圖續州造裂熊

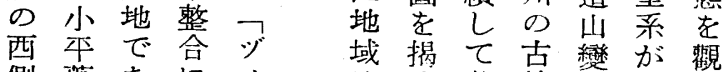

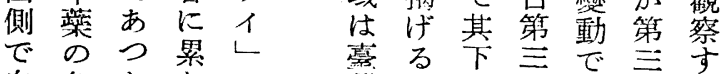
白各たな灣部系は系る 鍳念

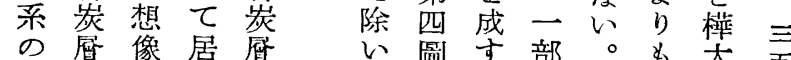

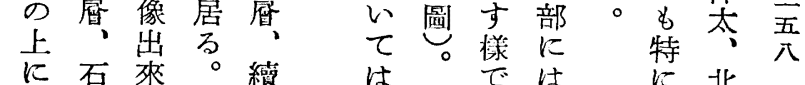
に石來。纉は岕は北

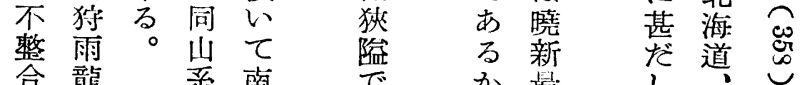

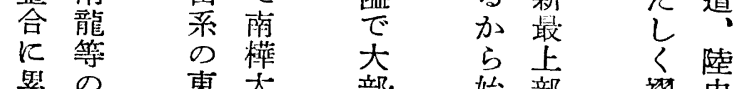
蓄学東太部始部褶中 さ含㑡の分新の 曲久 策 

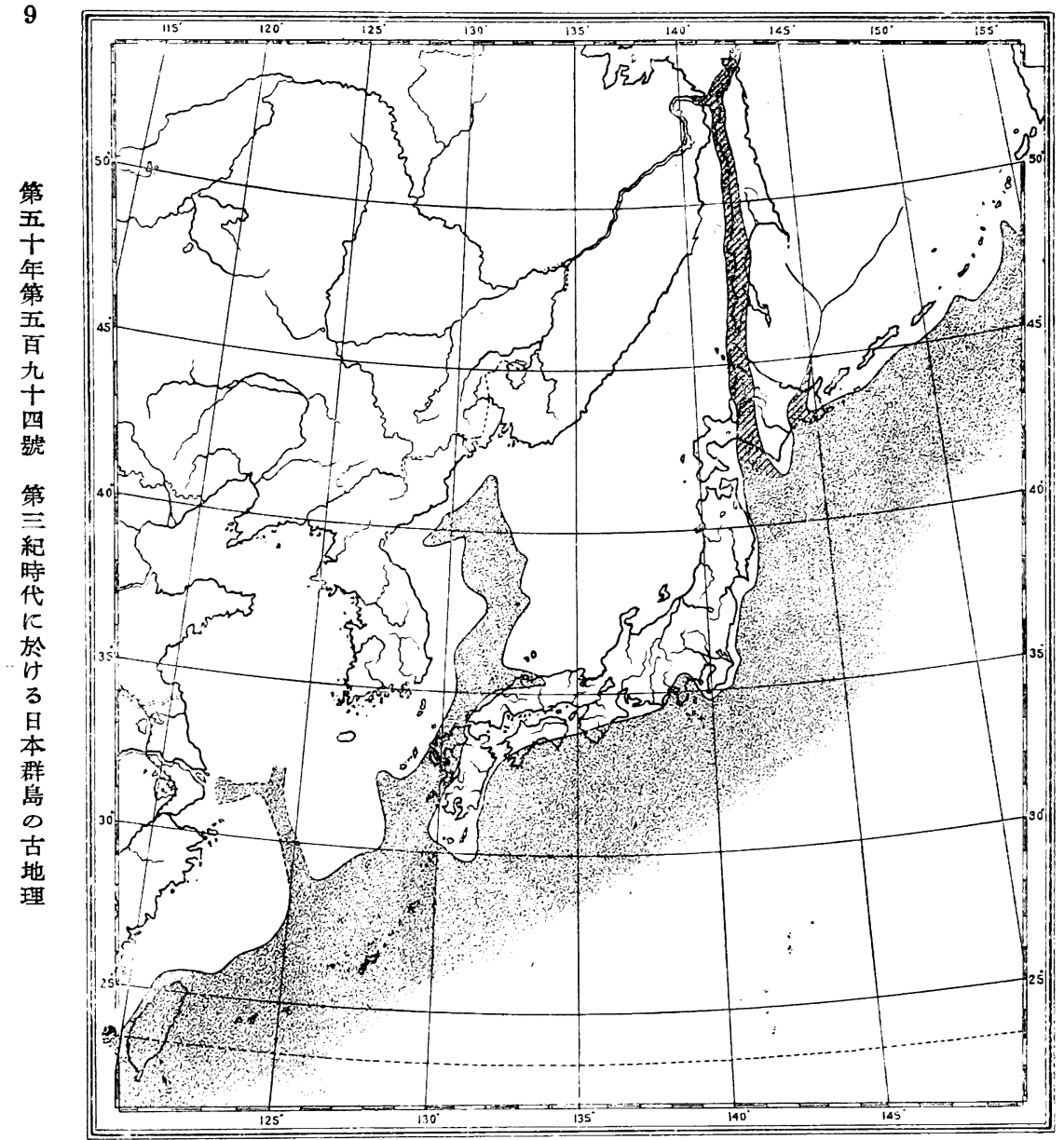

はり

陸又

化 ᄀ

乙 オ

居

万止

た

乙 海

$\varepsilon$ 全

に 部

なに

鬲

ま委

- 千

島

列

島

8

地

て

あ

t

の

で

は

あ

る

ま

w

吕

果

乙

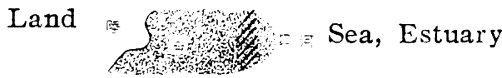

第五圖濑新世 Fig. 5. Oligocene.

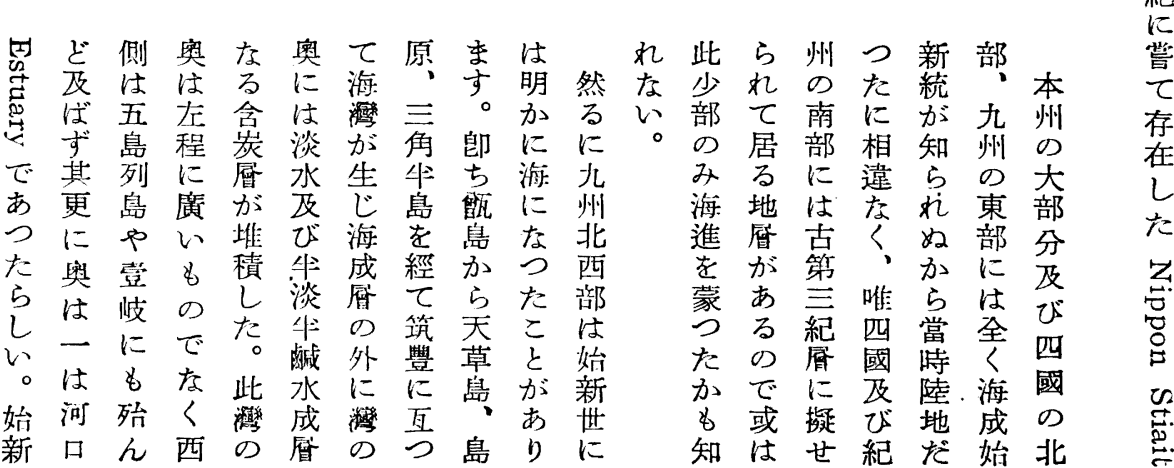




\begin{tabular}{|c|c|c|c|c|c|c|c|c|c|c|c|c|c|c|c|c|c|c|c|c|c|}
\hline 同 & 化 & 統 & 中 & & & の & & 蔽 & の & $L$ & 進 & & 始 & & 8 & & $\kappa$ & で & & 世 & 10 \\
\hline [] & $\begin{array}{l}\text { 石 } \\
\text { 深 }\end{array}$ & ご & 中 & & 琉 & 御 & 九 & U & 突 & た & は & 北 & 新 & 先 & 始 & 漸 & は & 或 & 南 & 虽 & \\
\hline Q & $\frac{x}{x}$ & $\succ$ & 秖 & & 球 & 坂 & 州 & 其 & 道 & の & 日 & 九 & 世 & כ゙ & 新 & 新 & 海 & は & 西 & 時 & \\
\hline 代 & 乍 & 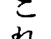 & 世 & & 支 & 統 & 1 & 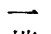 & 統 & で & 本 & 州 & の & 南 & 世 & 世 & 水 & 非 & 諸 & 日 & \\
\hline 代 & 9 & ג & 初 & & び & は & 四 & 端 & の & 此 & 游 & の & 時 & 檴 & の & & 下 & 群 & 島 & 本 & \\
\hline 石 & る & は & 期 & & 壹 & $\vec{\longrightarrow}$ & 國 & は & 地 & 生 & $\infty$ & 漸 & $\varepsilon$ & 太 & 8 & 北 & に & 島 & 及 & 海 & \\
\hline を & 地 & $<$ & & & 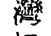 & 部 & 及 & 出 & 質 & 物 & 南 & 新 & 同 & 及 & の & 九 & 溥 & ま & $\widehat{\mho ゙}$ & の & 第 \\
\hline 含 & 層 & $\overrightarrow{8}$ & 下 & & に & 漸 & び & 雲 & 時 & מi & 西 & 統 & 樣 & び & $\varepsilon$ & 州 & L & で & 掌 & 存 & 呴 \\
\hline$\infty$ & の & $\stackrel{2}{3}$ & 部 & & は & 新 & 本 & 國 & 代 & 棲 & 部 & は & で & 北 & 殆 & 立立 & 去 & - & 灣 & 在 & + \\
\hline る & 地 & \$ & 中 & 新 & 有 & 世 & 州 & ま & は & ん & $に$ & 含 & あ & 海 & h & に & 台 & 般 & 島 & は & 年 \\
\hline 地 & 質 & 0 & 新 & & 孔 & K & 南 & で & 末 & だ & 及 & 若 & る & 道 & દ゙ & 北 & た & r & に & 疑 & 第 \\
\hline 屡 & 時 & ڤ્ & 統 & & 䖪 & 尿 & 部 & 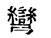 & だ & 海 & $\widehat{h}$ & 愿 & & の & 差 & 海 & $k$ & 海 & は & は & 五 \\
\hline は & 代 & $\overrightarrow{\mathrm{O}}$ & D & 第 & を & 5 & に & 入 & 判 & は & だ & の & 釧 & 下 & 異 & 道 & 思 & ह & 海 & L & 百 \\
\hline 朝 & を & है & 沈 & & 含 & る & 互 & $L$ & 然 & 南 & $\varepsilon$ & 上 & 路 & 部 & か心 & 庎 & は & 存 & 成 & $<$ & 九 \\
\hline 焎羊 & 參 & $\varepsilon$ & 積 & & $\bar{h}$ & 疑 & る & た & L & 方 & 想 & $\bar{\sigma}$ & 及 & 舍 & な & 南 & ג & 3 & 始 & 精 & $\begin{array}{l}\text { 四 } \\
\end{array}$ \\
\hline の & 照 & 云 & 時 & $\equiv$ & だ & が & 太 & と & な & の & 像 & 盧 & び & 吉 & $w$ & 樺 & る & た & 新 & ২ & 號 \\
\hline 東 & す & $\overrightarrow{3}$ & 代 & & 碓: & あ & 平 & す & $w$ & 四 & $\frac{1}{9}$ & 屋 & + & 愿 & & 太 & 0 & で & 統 & 北 & \\
\hline 海 & る & 化 & 老 & & 實 & る & 洋 & る & が & 國 & べ & 愿 & 勝 & は & 第 & ळ & & あ & が & 九 & 第 \\
\hline 岸 & $\varepsilon$ & 石 & 指 & 紀 & 疗 & の & 岸 & $\infty$ & 古 & を & き & 群 & 丽 & 上 & 五 & 漸 & & 5 & 明 & 州 & 67 \\
\hline 地 & 或 & を & す & & 漸 & で & の & で & 第 & 越 & 一 & で & 國 & 部 & 㘣 & 新 & & $j$ & 確 & に & 紀 \\
\hline 方 & は & 含 & の & & 新 & 始 & 汀 & あ & $\equiv$ & え & 事 & 藘。 & ळ & は & $\underbrace{}_{0}$ & 世 & & 0 & $に$ & 開 & $\begin{array}{l}\text { 时 } \\
\text { 代 }\end{array}$ \\
\hline に & 其 & 2 & で & & 統 & 新 & 線 & る & 系 & $\tau$ & 實 & 屋 & 含 & 漸 & & 沈 & & 其 & 存 & W & $\pi$ \\
\hline 長 & 下 & , & あ & & が & 世 & が & 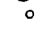 & た & 來 & ti & 蟹 & 咴 & 新 & & 積 & & 荫 & 在 & た & 於 \\
\hline 獎竞 & $\infty$ & $\underset{t}{\forall}$ & る & & あ & の & 那 & & る & た & あ & 群 & 曆 & 世 & & 甪 & & 方 & $\frac{1}{9}$ & 二 & け \\
\hline 統 & $D$ & $\Xi$ & が & & る & 時 & 邊 & & 疑 & $\varepsilon$ & る & の & $\sigma$ & に & & は & & 敏 & る & 低 & る \\
\hline$\varepsilon$ & م5 & ᄅ. & 本 & & מ & 代 & $に$ & & が & は & $\circ$ & 時 & 歺 & 入 & & 始 & & 是 & 老 & 地 & 日 \\
\hline 品 & 点. & $\begin{array}{l}\infty \\
0 \\
20\end{array}$ & 邦 & & 5 & $\downarrow$ & あ & & 濃 & 思 & 夫 & 代 & 洗 & る & & 新 & & 白 & 知 & 鞉 & 本 \\
\hline 明 & $\overrightarrow{\mathrm{S}}$ & 苟 & $に$ & & 此 & り & 3 & & 愿 & は & 风 & か & 8 & 樣 & & 統 & & 亞 & 5 & が & 碓 \\
\hline 川 & 蛋. & 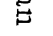 & 於 & & 地 & 8 & た & & డ゙ & れ & は & 5 & 略 & で & & $\varepsilon$ & & 紀 & れ & あ & $\begin{array}{l}\text { 島 } \\
\Phi \\
\Phi\end{array}$ \\
\hline 秒 & $\stackrel{\mathbb{E}}{\rightleftarrows}$ & $\stackrel{2}{\rightleftarrows}$ & $\tau$ & & 卞 & 此 & מ & & あ & $ぬ$ & 山 & 此 & 昰 & あ & & 相 & & $\sigma$ & $\tau$ & 3 & $\begin{array}{l}\text { s } \\
\text { 古 }\end{array}$ \\
\hline 下 & 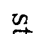 & $\mathscr{Q}$ & 明 & & は & 方 & は & & る & 0 & 陰 & 沈 & 同 & り & & 件 & & 時 & 居 & た & $\begin{array}{l}\text { 只 } \\
\text { 地 }\end{array}$ \\
\hline 部 & है & 0 & מ & & 海 & 面 & 俄 & & 。 & 恐 & 伯 & 積 & 樣 & ま & & $S_{2}$ & & 代 & $\tau$ & 位 & 理 \\
\hline$\sigma$ & (0. & を & に & & 進 & $K$ & k & & 故 & 5 & 惹 & 海 & で & す & & 8 & & $r$ & 此 & $\varepsilon$ & \\
\hline 坪 & & 包 & 下 & & を & は & 明 & & $\kappa$ & $<$ & 國 & 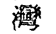 & 當 & か & & の & & 存 & 方 & 思 & \\
\hline 六 & $\pi$ & 容 & 部 & & 蒙 & 海 & か & & 漸 & 西 & 日 & に & 時 & 5 & & の & & 在 & "面 & は & \\
\hline 洞 & で & 于 & 中 & & 3 & 進 & r & & 新 & 方 & 里予 & 海 & 海 & 其 & & み & & L & は & れ & \\
\hline の & $k$ & る & 新 & & た & が & L & & 世 & 日 & 站 & 潮 & 陸 & 洗 & & $に$ & & た & 海 & 万 & \\
\hline 地 & 8 & $こ$ & 統 & & $こ$ & 奥 & 難 & & 海 & 本 & 新 & か & の & 積 & & L & & c & で & 0 & \\
\hline 層 & 人 & $\varepsilon$ & $\varepsilon$ & & $\varepsilon$ & ま & $w$ & & 進 & 海 & 屋 & 進 & 範 & 䀂 & & $\tau$ & & 想 & あ & & \\
\hline 等 & ১ & は & 證 & & が & で & が & & は & מ & 及 & 入 & 犐 & 地 & & 隨 & & 像 & 3 & & \\
\hline が & $\begin{array}{l}\text { s } \\
4\end{array}$ & 莗 & 明 & & 明 & 及 & 始 & & 天 & 5 & $ひ ゙$ & L & 8 & は & & $\tau$ & & F & 72 & & \\
\hline あ & 知 & $k$ & せ & & 力 & h & 新 & & 草 & 信 & 多 & た & 炲 & 南 & & 其 & & 5 & & & \\
\hline 7 & ג & 外 & 5 & & で & だ & $-H E$ & & 0 & 入 & 里 & $こ$ & 新 & 北 & & 沈 & & れ & 恐 & & \\
\hline & & づ & れ & & あ & か & の & & 灘 & L & מs & $\varepsilon$ & 世 & r & & 積 & & た & 5 & & \\
\hline 又 & 0 & れ & た & & る & 8 & 時 & & か & た & 5 & が & の & 長 & & 窃 & & & $<$ & & \\
\hline 薩 & & る & 地 & & 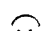 & 知 & $\varepsilon$ & & 5 & 8 & 明 & あ & 時 & $w$ & & 地 & & 2) & 筑 & & \\
\hline 醅 & & $こ$ & 歴 & & 第 & $\not L$ & 大 & & 北 & の & か & る & $\varepsilon$ & & & は & & 5 & 些 & & \\
\hline 多 & & $\varepsilon$ & は & & 五 & $\alpha_{2}$ & 同 & & 九 & $\varepsilon$ & $k$ & の & 大 & $\sqrt{2}$ & & 同 & & 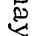 & $\sigma$ & & \\
\hline 臭 & & は & 中 & & 橉 & & 小 & & 州 & 想 & 漸 & は & 差 & $\vec{E}$ & & $\ldots$ & & & 毎 & & \\
\hline$\sigma$ & & な & 國 & & $\mho_{0}$ & & 異 & & 孝 & 像 & 新 & 明 & な & 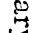 & & 坫 & & $\overrightarrow{0}$ & 㾞 & & \\
\hline 租 & & $w$ & 山 & & & & $\hat{\varepsilon}$ & & 經 & $\frac{1}{9}$ & H & 力 & C & & & 所 & & & か & & \\
\hline 子 & & o & 地 & & . & & 思 & & $\tau$ & る & $t$ & だ & $\varepsilon$ & を & & & & の & 5 & & \\
\hline ケ & & 東 & 队 & & & & 3. & & 日 & & & & 想 & & & & & 大 & 南 & & 六 \\
\hline 島 & & 印 & $V$ & & & & 0 & & 本 & 出 & 示 & & 煥 & $\sqrt{2}$ & & 在 & & 陸 & 阮 & & 0 \\
\hline $1=$ & & 度 & 散 & & & & 唯 & & 海 & & 示 & 串 & 像 & L & & る & & it. & に & & \\
\hline 在 & & 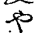 & & & & & & & & 管侌 & g & に & 9 & $\tau$ & & か & & 恐 & 連 & & $\stackrel{\omega}{0}$ \\
\hline り) & & 兰 & & & & & & & 9 & 國 & る & 漸 & る & 居 & & 故 & & 5 & 續 & & 8 \\
\hline$\circ$ & & 旵 & & & & & 山 & & 斛 & 宾 & 化 & 新 & & 3 & & に & & $<$ & L & & $\smile$ \\
\hline 琉 & & で & 植 & & & & 附 & & 西 & 道 & 石 & 壮 & & た & & 其 & & 始 & 薣 & & \\
\hline 氷 & & 同 & 月 & & & & 近 & & 部 & 솨 & 老 & の & & 事 & & 分 & & 新 & 灣 & & \\
\hline & & & & & & & & & 孝 & 島 & 產 & 海 & & は & & 作 & & 期 & ま & & \\
\hline
\end{tabular}


11

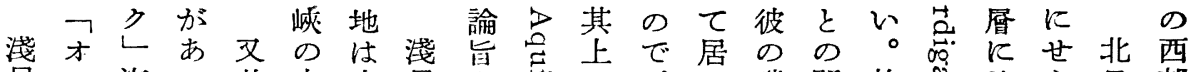

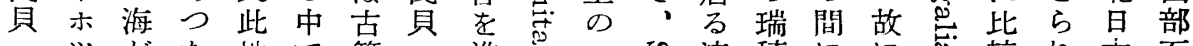

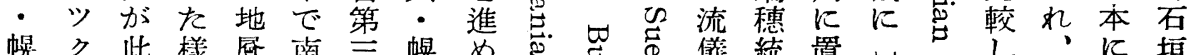

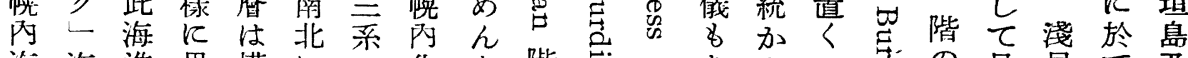
第 湤 海 進思櫵に

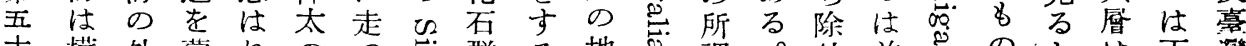

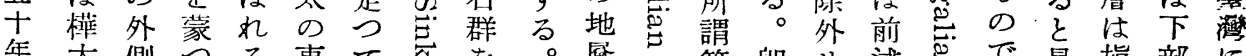

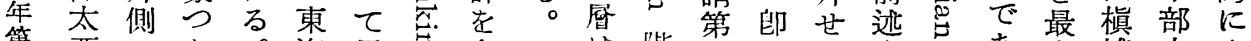

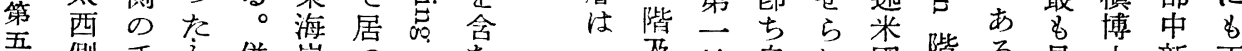

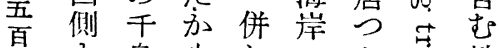

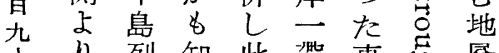

四北島到地に智事怘曆

號海にぬ愿はなに北 道はのは碓る沿は

第の 淺で樺賽のひ陆

紀中貝、太索で大太

紀次・果最多あ”部の

代四幌し北のりは北

に地内为て 未ま重端

於帶化然口柜与複文

け存不 り シ 發第た 同

る 䝨群をとさ見第た 同

本势含る

脽忽めとだれ苹あ西

の洋る 前しずする牛

古に地記牛、紨部

地連愿の島强此を

理なは乾にい地挫

る見陸的て 唇ひ

こ當は在想は北

とた恐り像沿海

はらら、守海道

明なく制る州の

か心二路と穴

でか大古北方央

あら島幐樺、に奉

る玆と雨太 無梁

○に存國東

南\&るに斗名脈

当陸。安部施の

に及之發か 此西

下び壳見ら淺侧

己島南せ北 貝に

てが蝦ら海

奥 あ 夷 れ 道

幌 互

狗つケて中

队 り

范地自れ 圈階る 見士: 新下

其中分基态共。異に統部 灾 下 海 が 居平 共 占 总

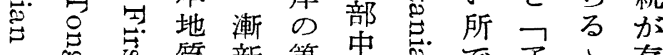

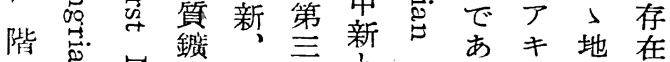

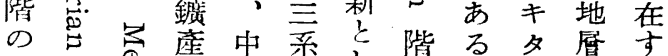

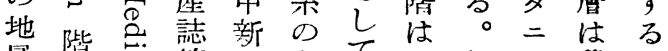

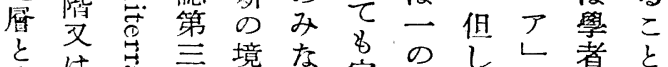

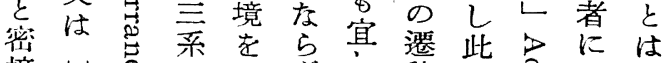
接怘怘只

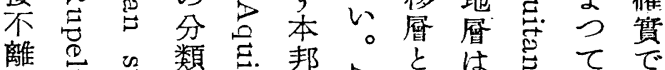

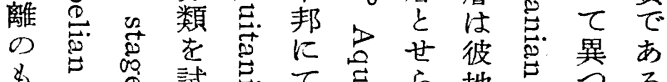
の 階に み とのにた階此吉必於と居 認地相時の法导ずて せる

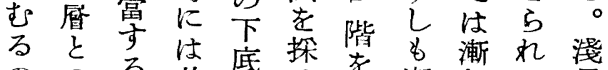
ののる此底る 棌漸新て 貝 で相名法置者新新統居・

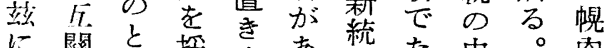

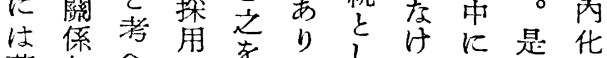

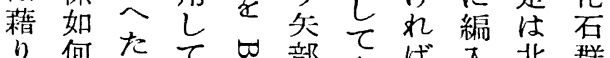
り何たて㢇部漸ば入北群

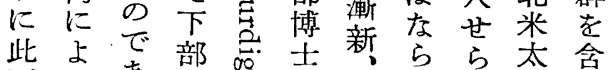

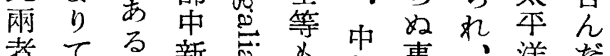

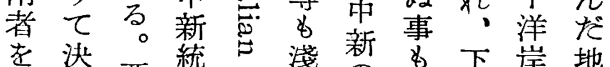
共せ 決 要統階貝 境な 部 にら點ちと 下るは新共幌界、中加は 三地た島居央

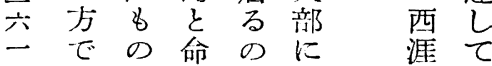
はと名で瓦は居

其し古賞つ 今

海萧 る 時て 日て $\begin{array}{lllll}\text { 洋 } & \text { 置 } & \text { の } & \text { 其 } \\ \text { く } & \text { オ } & \text { 間 堆 }\end{array}$ 西。乾宮積 涯陸海盆 部べ第に內內統やは 中き号品中化同新 新で亲系新石階に新と卡新

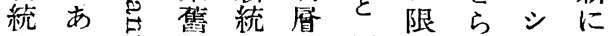

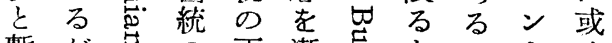

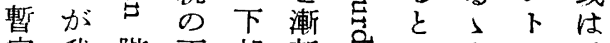
定我階下部新 只云 至之 又 し日の段に統鸟ふ心のして下 置本地と編と荧事は州部

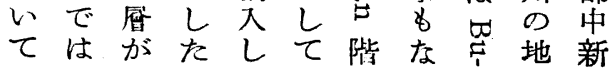




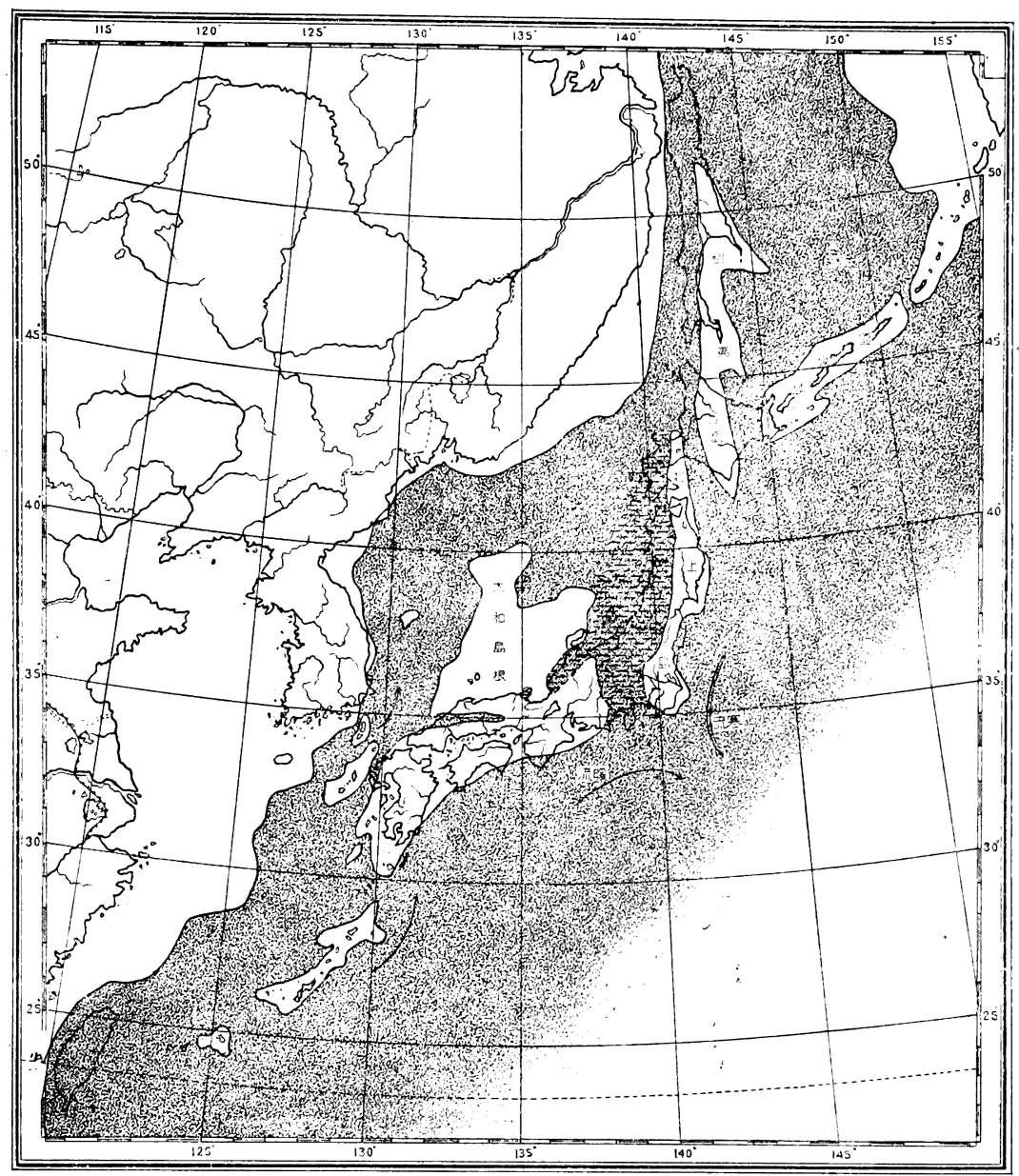

積は

12

が 北

起 上

た阿

- 武

陸隈

中 山

久地

地策

方 緗

にに

\& 在

上D四

激た 號

白 こ 第

采 明 三

の 嘹

上 で

に現に

白今 於

水にけ

統 近 る

と 似 日

同し本

樣乙 翡

岩居

層り古

老唯地

含阿理

め武

る、縟

一山

地 地

畠

が 東

存 䜌

在心

Land 陸

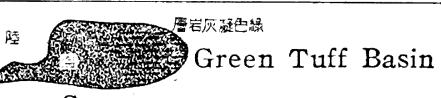

すは

る 海

か 進

第六圆 中新世古期 淺只・䗷內・植月期 Fig. 6. Early Miocene. 常 蓬

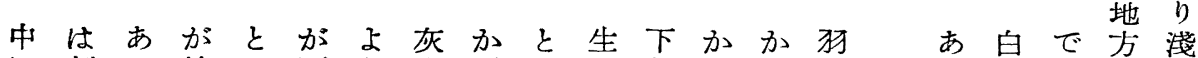

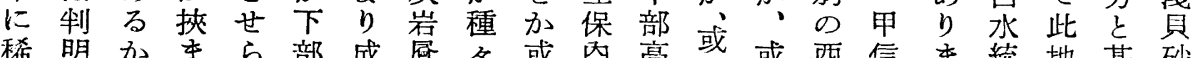

々或內高曆或西信ま統 地 甚 砂

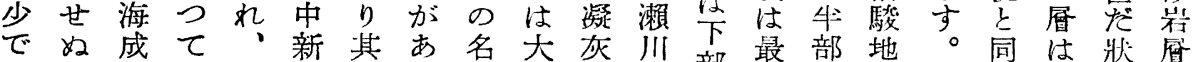

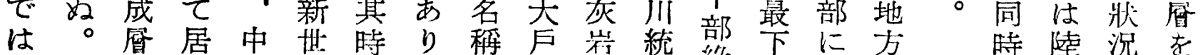

あ面でるに或代、で瀨畨と線部互か

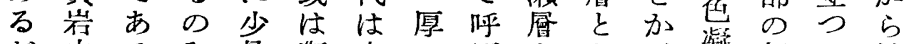

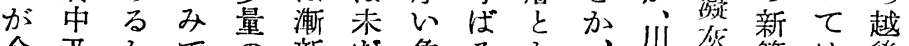

介及かでの新だ角るか、不监第は後

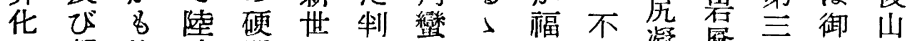

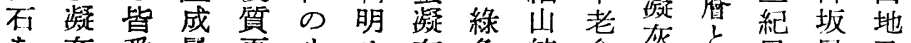

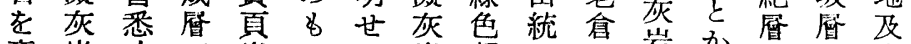

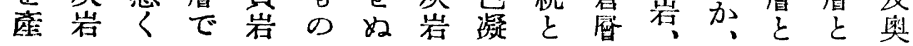

代成 が 含 六

か 厤 類 女

\& 加似る

知主し白

れでて水

ぬあ居統

のるるの

でがの堆 


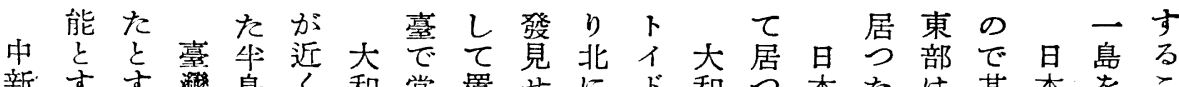
新すす溜島く和當置せにだ和つ本たは其本を島を 初べにな逼島時いら入し堆たのと當海海形と 期き可はりつ根のたるり陫にと本と時はが成が のでき前しての顀方】込よ酷假陸方存園當しあ 第火李で迅な來南火が樣んり似定であ否東時てる 吾山活

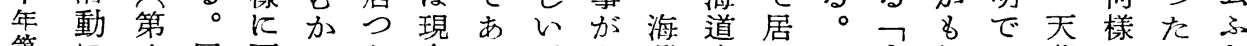

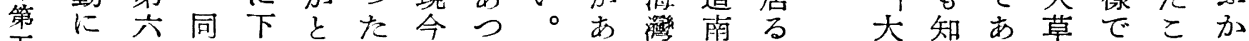
五就圖樣部想少のた何ると西子和れる灘あるとら

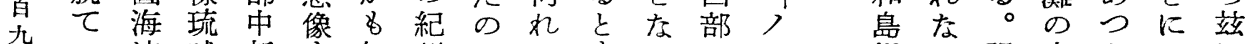
十三流球新玄知州でのするにト根い强方たた

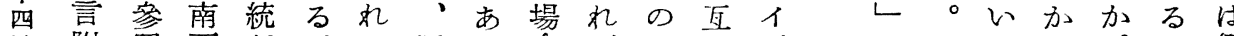

號附照西が。ぬ四る合ばでつ

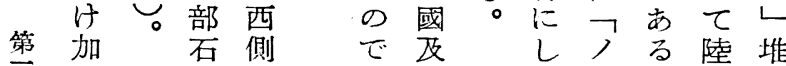

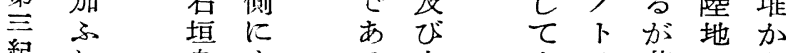

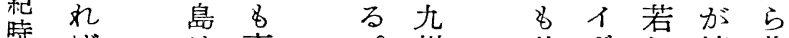

代ば楼東

に㮖海 側

於太

す 花市名

本 海

群道

$\infty$

地

理

殊 互潉方
理

䟽南海

の 加梁

沈 ら山

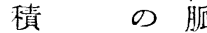

時潮 が

代流 島

の 加に

初 流 成

め和り

にて居

は 日つ

火本た

山磼 西 と

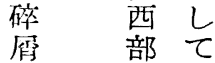

岩に\&

は通島

三 殆

六 ん

$\begin{array}{lll}\text { 皆 樣 } & \text { 部 } \\ \text { の } & \text { 分 }\end{array}$

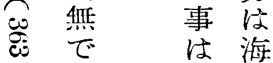

䩀 に

$\begin{array}{lll}\text { る゙ } & \text { 澓 } \\ \text { 其 } & \text { 不 } & \\ & \text { 可 }\end{array}$

\section{$\circ$ 州}

薩

简 萳

島

琉部

球

沖苦

繩 た

列 遠

島く

等は

當 W

時 样

陸 で

地 薩

ら南

し種

或子

は島

島は

で海

あに

万被

加 は

或 れ

は又

九日

州向

荫 油

端附

占近

b) 8

突 㳳

出店
此ドし續 北

沈し是 い海

積 堆等

游少の居に

にら凝つ互

は北灰た れ

安海岩とる

山道愿假現

岩にが定今

につ貝れ日

粒て幌ば本

狀陸队前海

安地統記 の

山をとの部

岩想同御分

等 像 時 坂 は

のす代愿陸

綠るの支で

岩必\&岕

や要の綠つ

石的色昔

英な證寲 か

安〈明灰又

山此 岩海

岩㽬ら愿で

やわ市

粗第乃沈了

面六㦧積た

岩㘣に盆加

等 $は$ 地不

がの例は明

旺樣へ樋で

盛にば方あ

に海浅殷る。

質涺貝河。

し一石方は

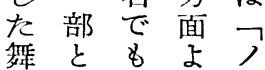

r

當

時

烥

k

存

在

L

の

で

あ

る

が

其

北

摭

摭

が

壮

何

處

な゙

あ

た

か

不

明

で

賞

大

和

堆

で

莚
てら。の假

考對中でに

ふ島國 あ 海 れ海山り成

ば陝地ま層

明或 のすと 川は植。看 統五月

の 島 統

化 列 p

石島朝

にの蘚 然

は南東

浅一東 海

貝侧岸

化等の は

石を長奥

と經 譼 牙

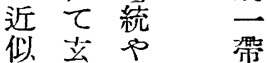

の海 明

種よ川 海

8 統 進

あ 日

る本 坡

力海 六

5 西洞

日 部 魔

海 港 は

の 入 明

西 乙加

部をな

等阿

東の南隈

部 ら 海 の

と ᄂ 性 雨

はいの 山

然化 は

でる石打

連にをち

絡旦本縞

て海る 


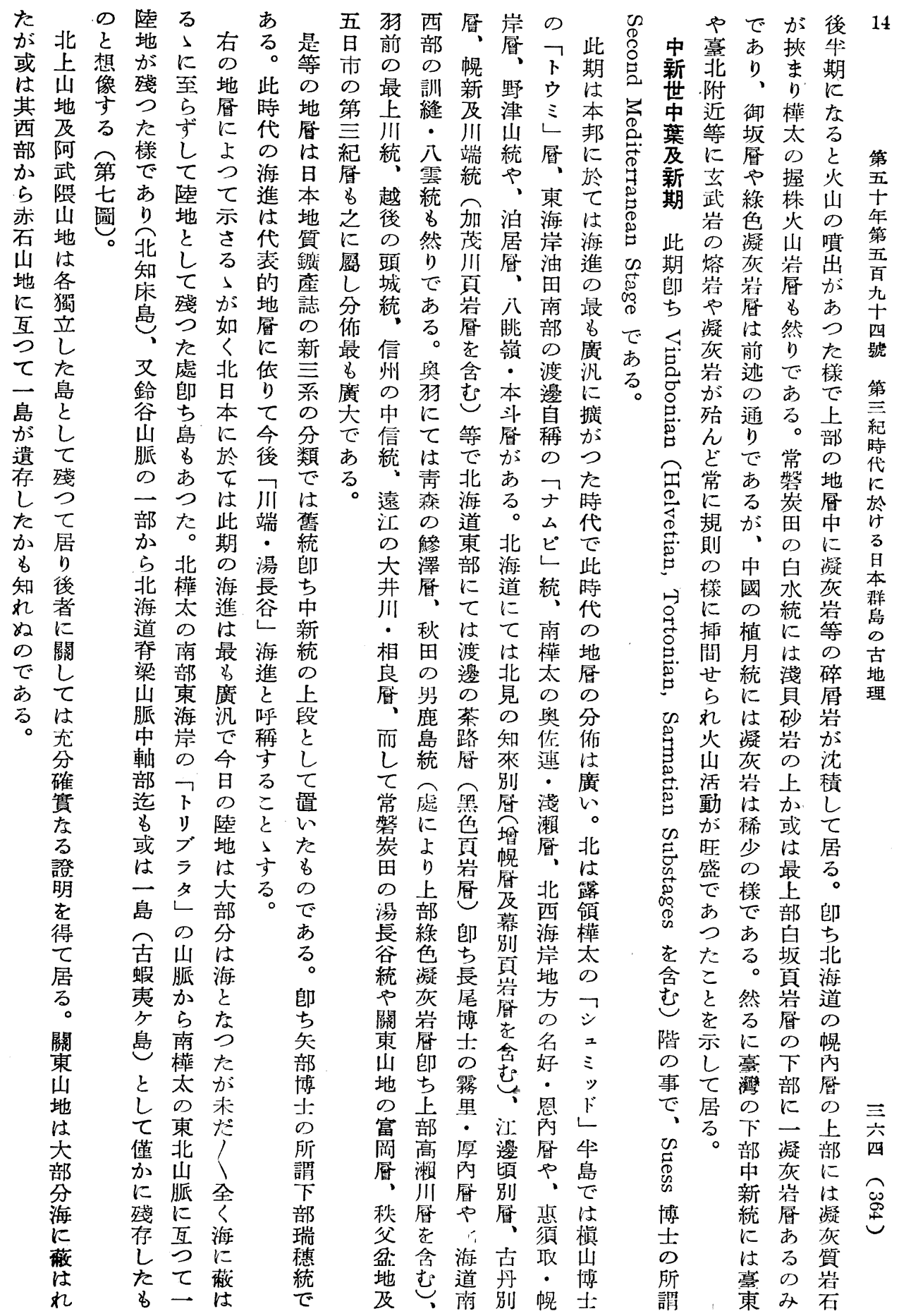




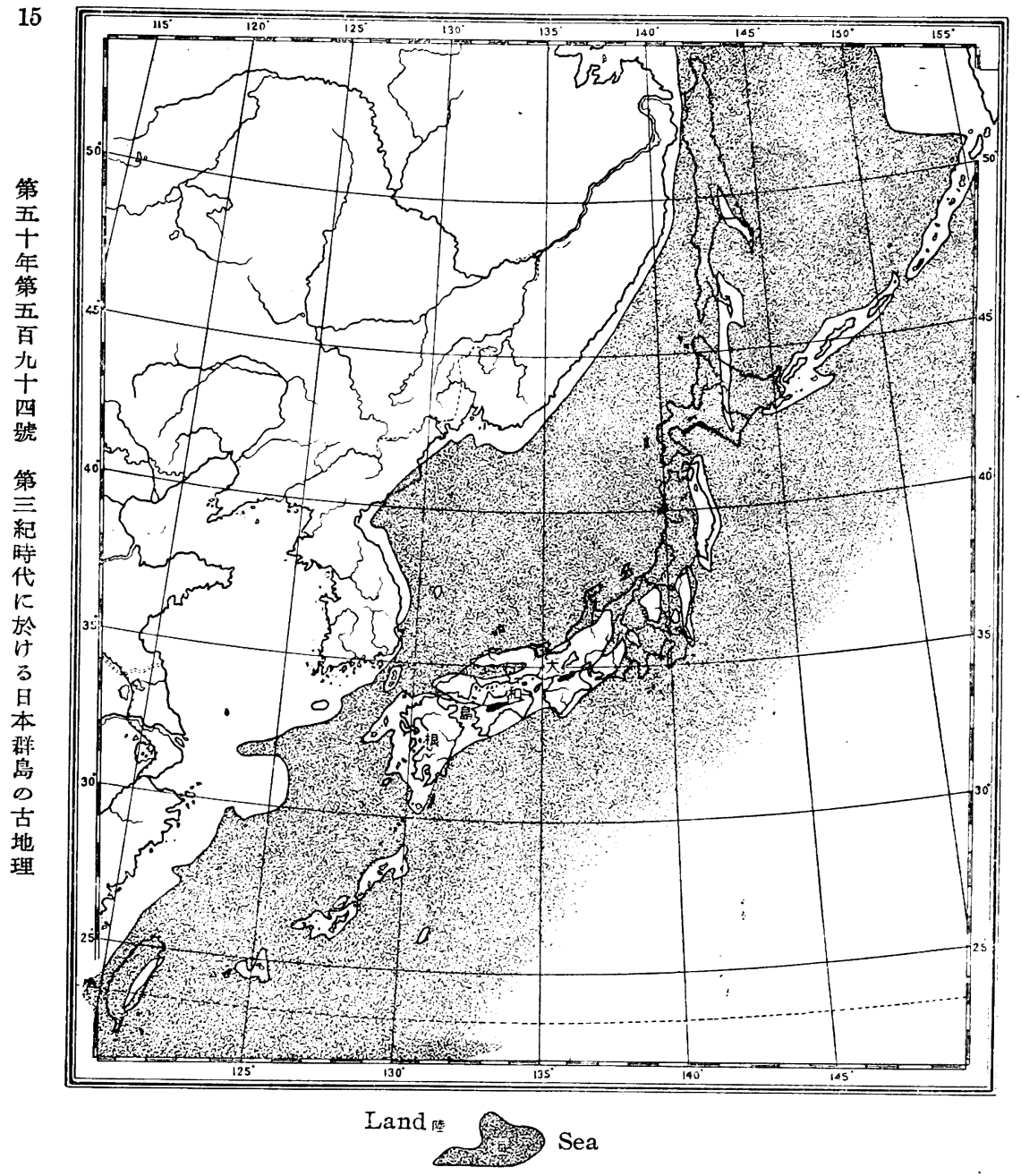

東

岸 本

に 海

て

は 現

中 代

新

䚹 樣

初に

期 䧹

と<

同疗

樣 つ

r

其々

南 想

東注

の れ

端 る

延 其

日 海

地 波

方は

吉 越

州

明 能

川登

地

等 西

加北

海 陸

にの

蔽 沿

は岸

x

长。

恩

第七圆 中新世中葉 川端、湯長谷期 津山、海山後牛期 (瑞穂古期)

Fig. Middle Miocene.

粕線につ千造らをるの新部込涪新が上沿

居に大て米線參﨎信上方䖻炭みは世中に中海

飞近和居以飞遠守州り加飞界來西初部は國地

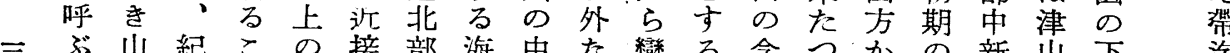

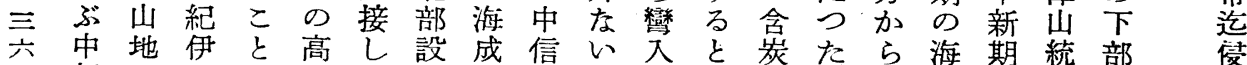

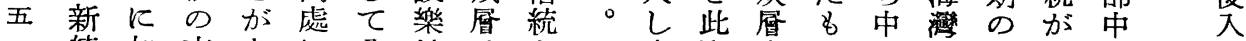

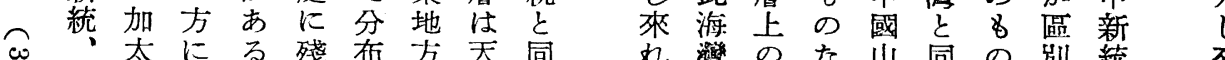

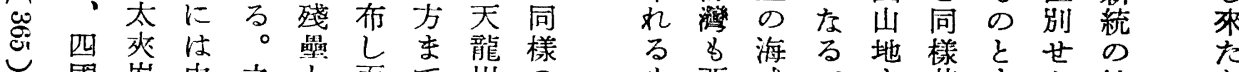

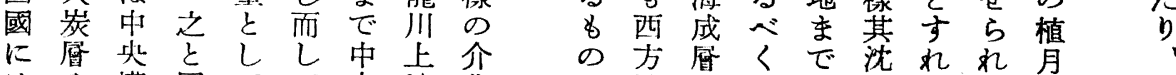

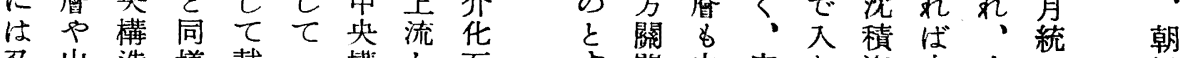

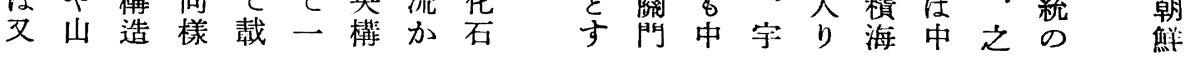




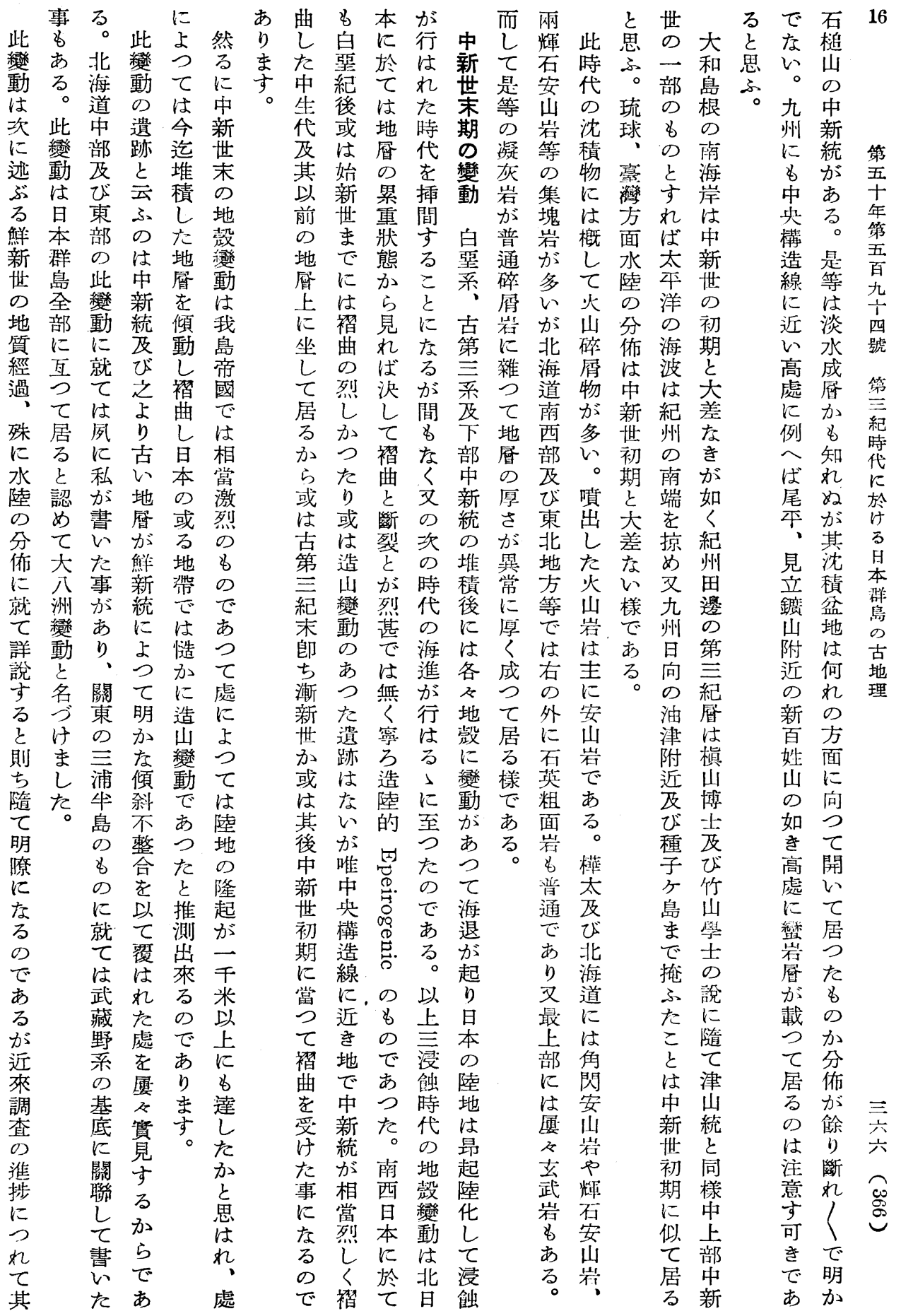




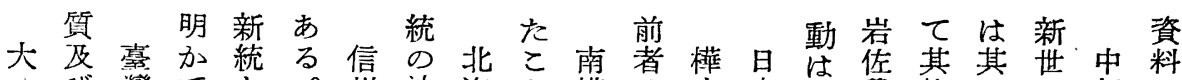

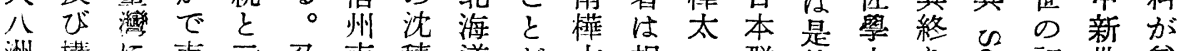

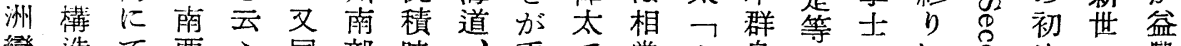

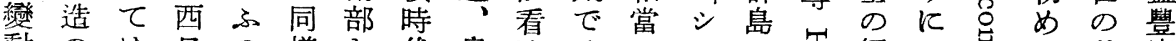

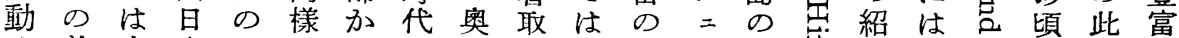

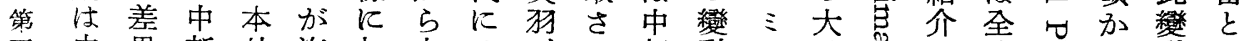

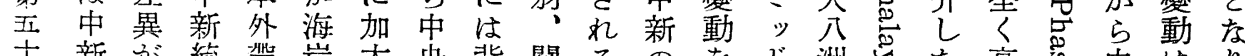

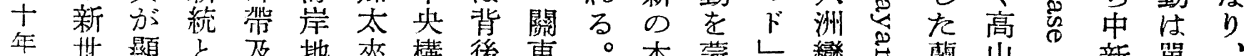

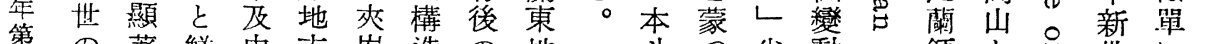

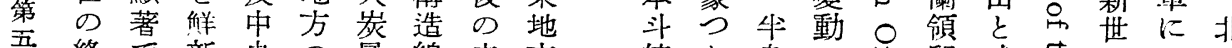
百終で新英の愿線赤方統た島の节印成吉の昆は 九末あ統構小やに石等等ので證品度り終本桠 十にると造區山近山の究では跡怘で切出頃群太 四最と肪線 域粕く地事

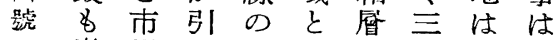
激川き地かが河已前 第 烈雄續滯 或中國にに

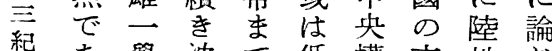
あ學沈で低構方地留 代つ士皘共岳造に架た にたがしに陵線互昂事 於が記た造地附う起が 其載地山の近てし あ る前し愿綏みの中てる 早汃飞動飞山新居加 本䊒 居思が在地統つ 悲始らは起るにがた省 のまるれつ許在分飞略 古りるてたりり佈槾し 地期 が居とで、し出て

理間中る云あ四て博南 の新がふる國基士西 永世夫事少石底少日 くのれがら牌礫論本 續末に容是山岩じに 、期 \& 易等 $の$ 方て就 たに拘に中高海居て \&臺は結新處拔占二 の灣 5 論統に一れ言

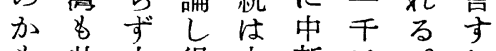
\&此中得中新三。れ 知 變新 5 新 統百 れ動のる期が米 ぬを臺〉の載の 事蒙北。終つ高 出統

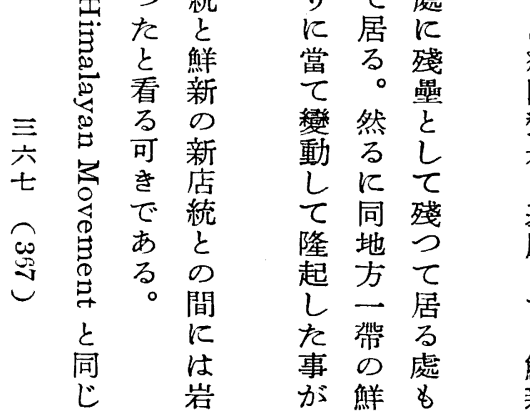
ば 遠

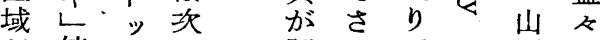
间統クの 解る 薪就の の 博て 凤 新の岂大み南

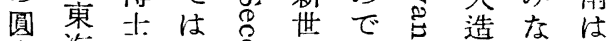

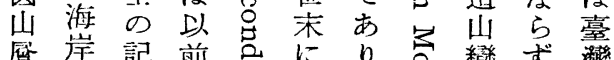

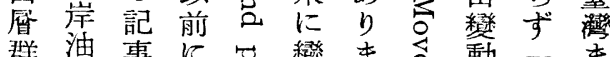

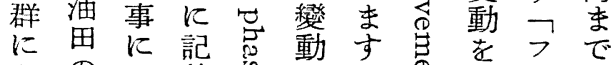

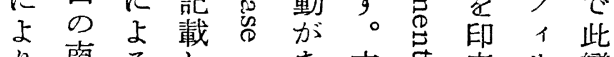
り南るし 部々 あ支古度り變 整で同所常て

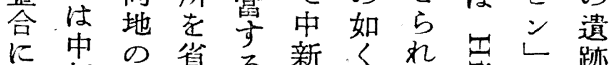
被新中心省る新新て志群䟽 は の 新て の

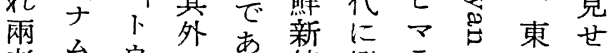

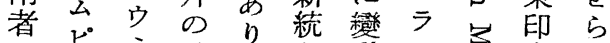

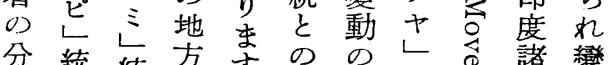
佈 統統方す

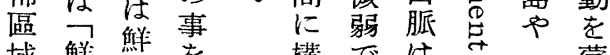

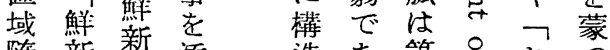
随 新新添造あ第只七つ

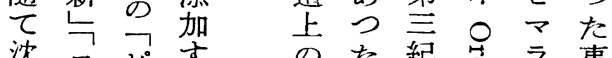
沈コピす の危紀芯ラ

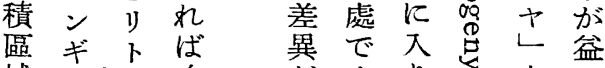
認へてと脈明

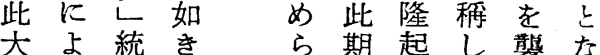

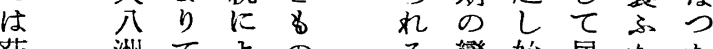
荻間繂不 り

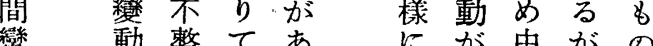

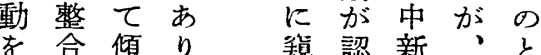
隔に斜ま はめ世此思

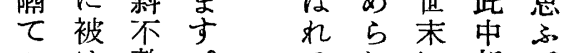
小は整。るれに新 餘文合 程てに 違居被

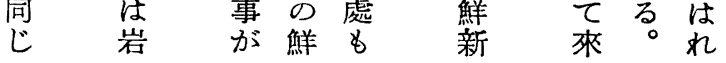
。る 最世第 大と安末 八云隆の 紀 洲ふ起 櫂 の 變。し動 瀬 


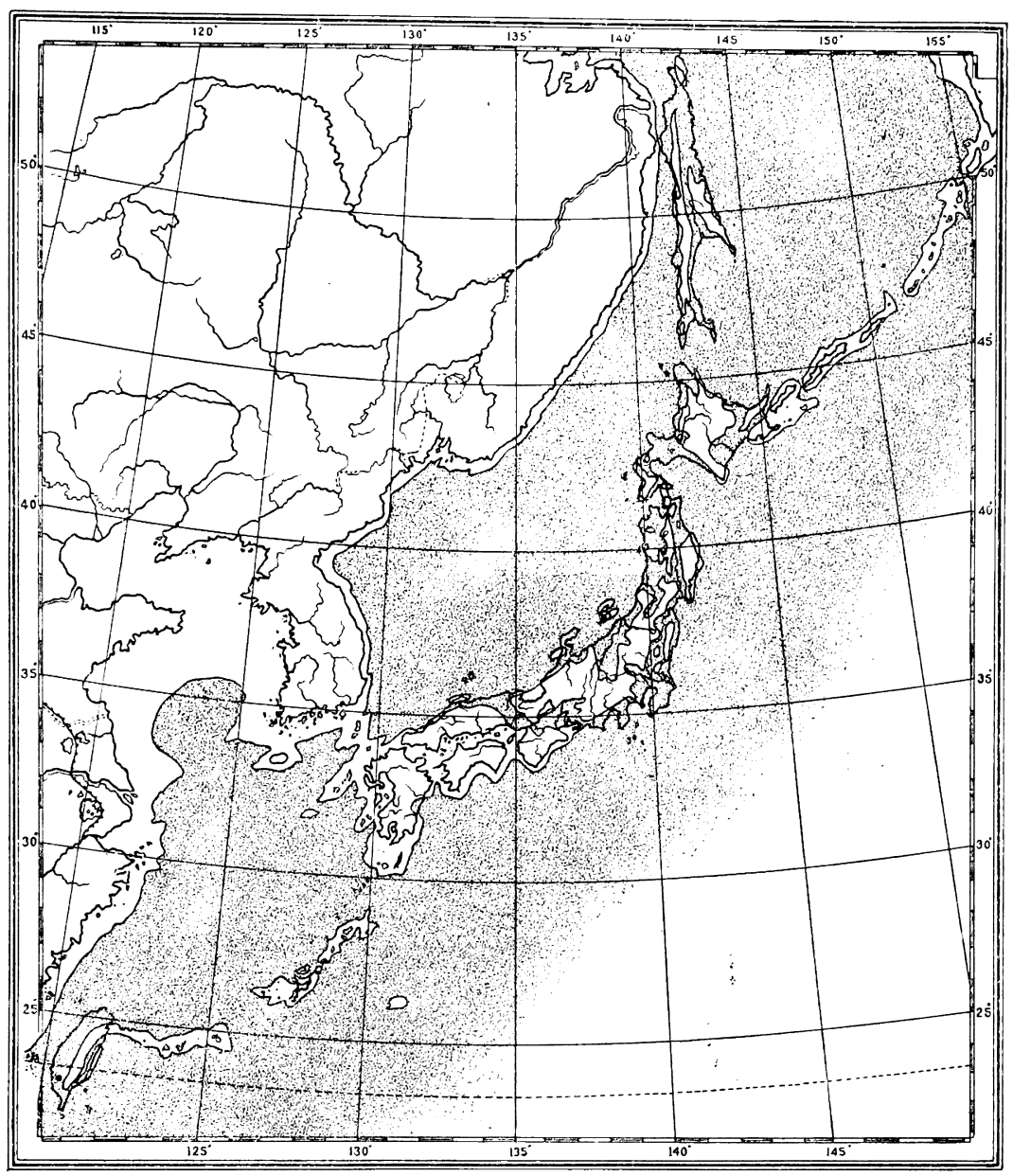

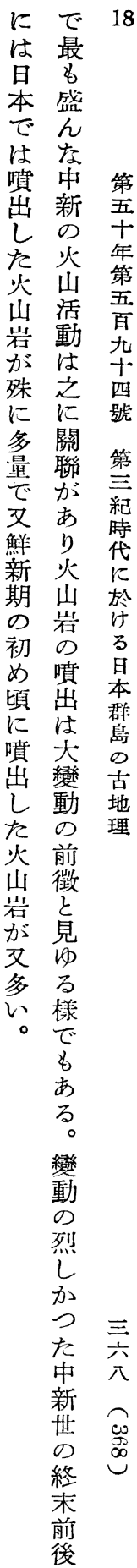

筙入圆 货新世古期 中越、白土、苗栗期 (瑞䅹中期) Fig. 8. Early Pliocene.

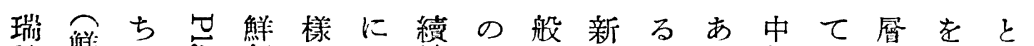

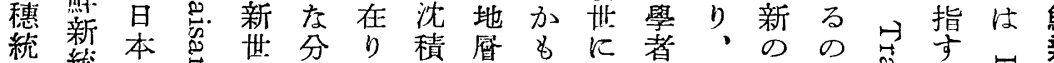

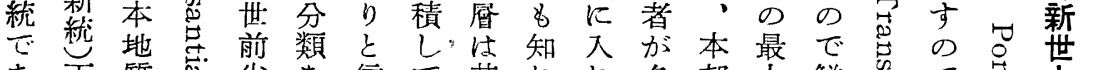

あ下㑭总牛を信て其れれ多邦上㙰总で总古

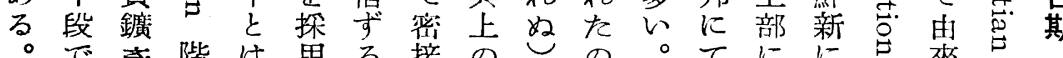

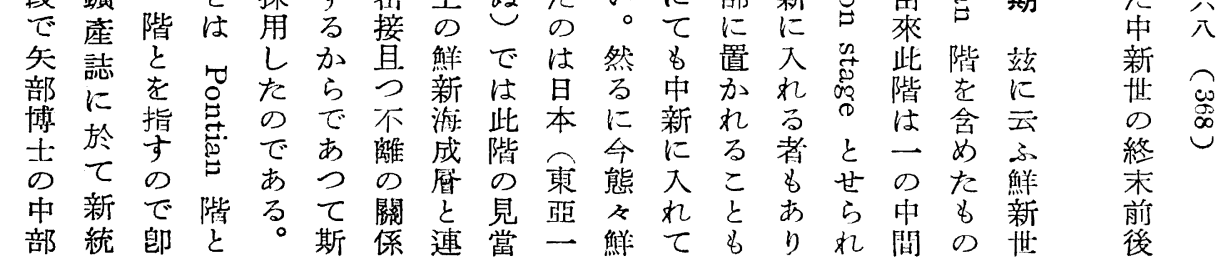




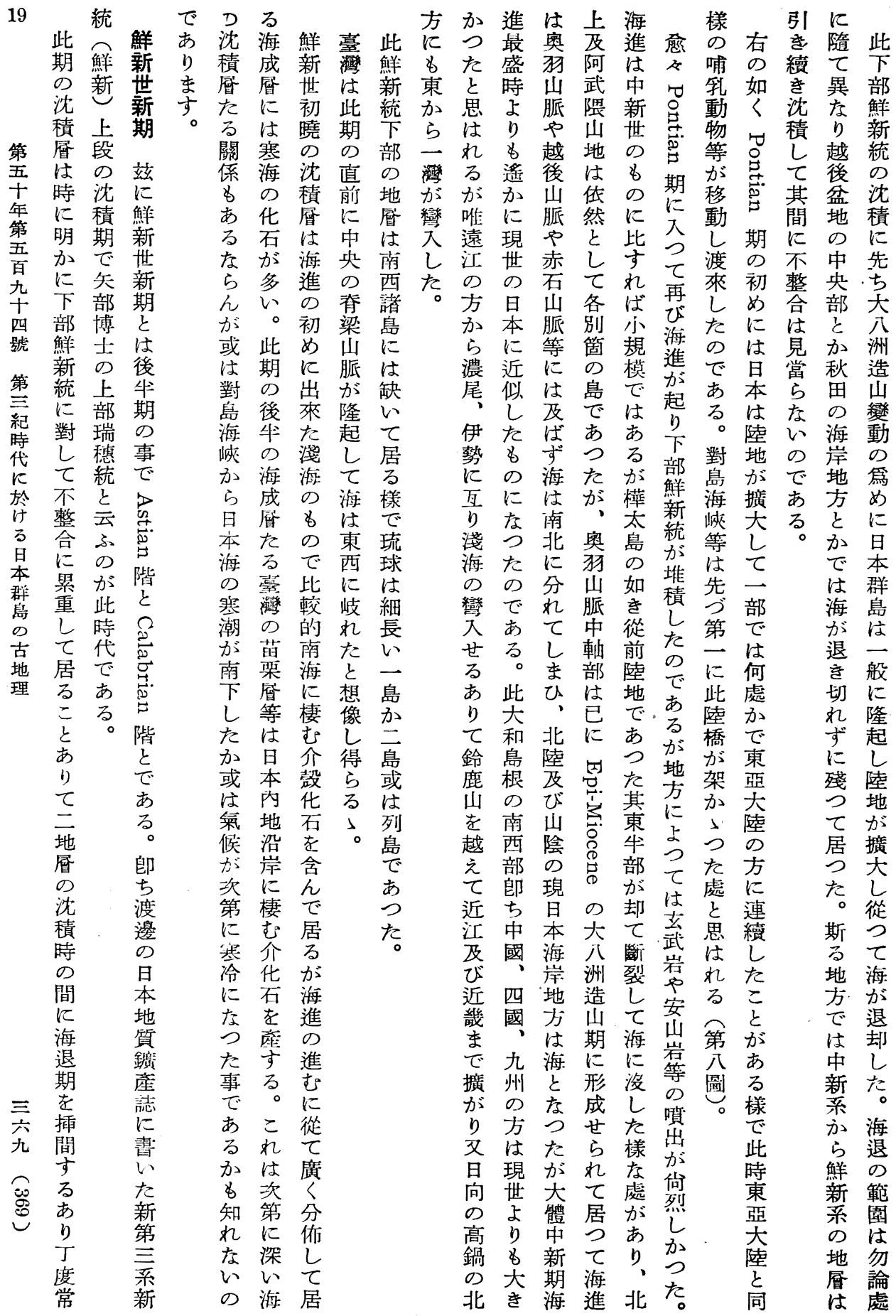




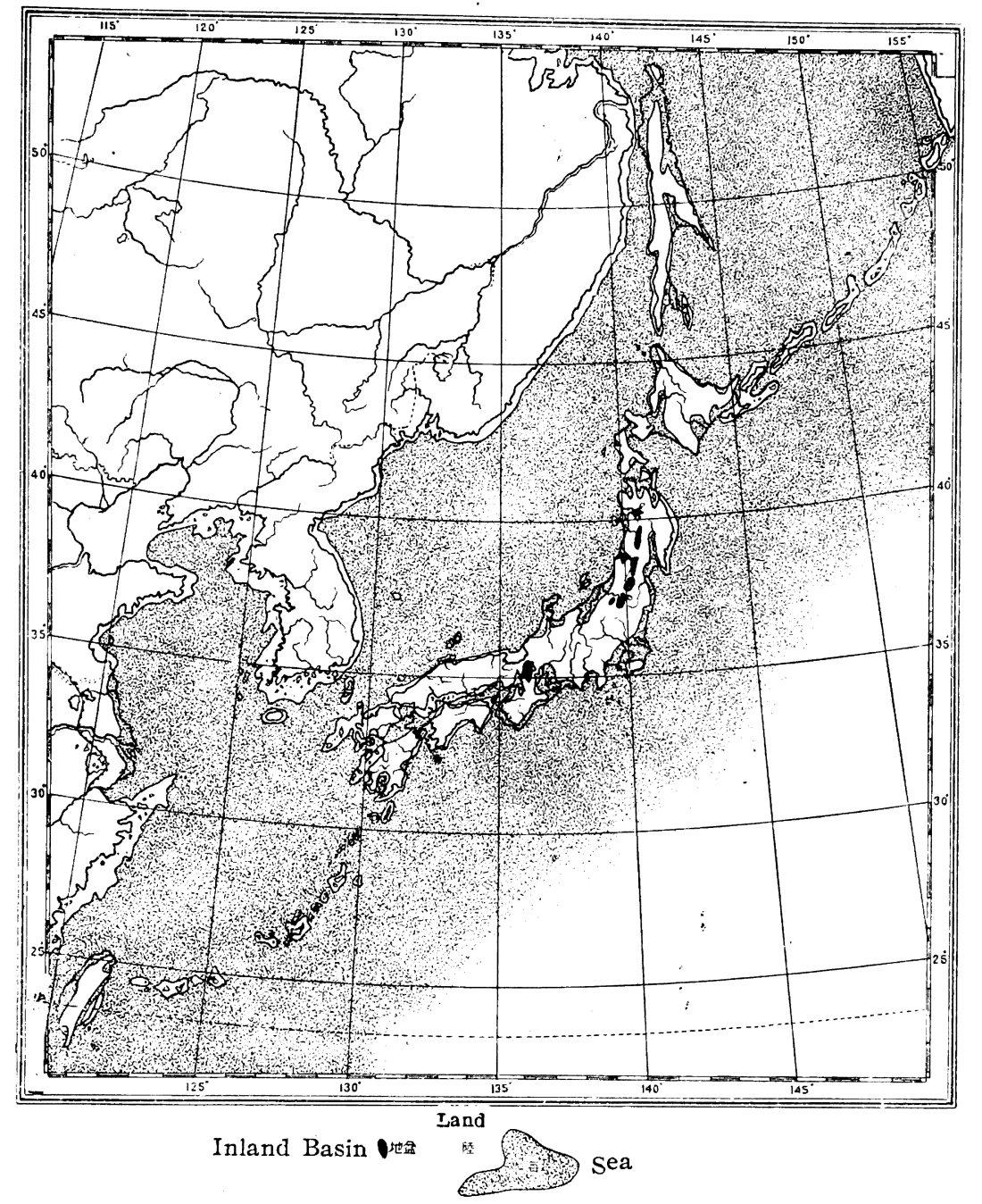

に䑾 20

口炭

口田

10

力 多

ラ 賀

1 統 筑

ズは吾

ᄂ 其十

乙 好 年

た例符

傾 で 五

间其 九

に後 卆

あ更四

つ 號

たて

樣 海

で 進

り起

却 2 代

てた於

下のけ

部でる

解あ 日

新る本

統が 留

海 然古

成 ᄂ 地

厝日理

が 本

次 全

第 船

に加

此 ら

期 見

にれ

入ば

つ 斯

て の

瀕 如

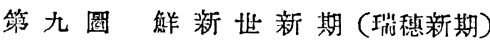

Fig. 9. Late Pliocene.

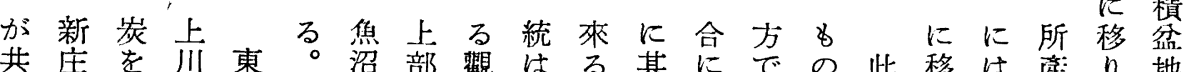
はる其にでの此移は童り 地

上地內 地 地

部のる留 方

解 石 地にで

新英層互 は

統 砂 がつ 仙

に愿あて籇

屬最り埋附

寸含山 木 近

る 亞 形 或 加

秋腐 縣

統 鮮が北樣間糸はは時る生の沈の

に新あはでに重下關代\& 淡觀積更

よ統る常あ 浸し部東の挑を物新

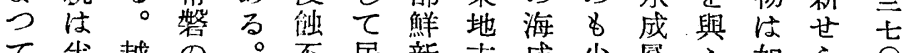

て半越の。不居新方成少愿孔如ら○

代淡後多閣整る統の愿存やる何れ

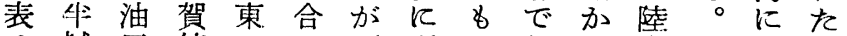

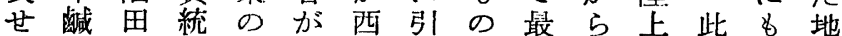

ら水のに上現方をで\& ずの 期海域

れ成方連部はに續房著市堆の泿は

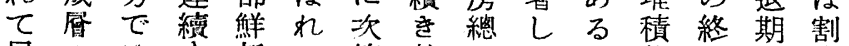

居のは䈤て 第整のい。物沫の合 
21 海州沈 8 染の溪積近出し愿砂田

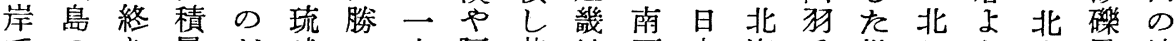
でのり后が球つ少阿其地西本海兵樣日り海層油 あ岸には終列て部蘇西方日海道陵で本連道が田 るを朝苗期島次海、方吕本沿ははあの續南あで こ洗蘚栗に第岸九只で岸南此る是し西る。

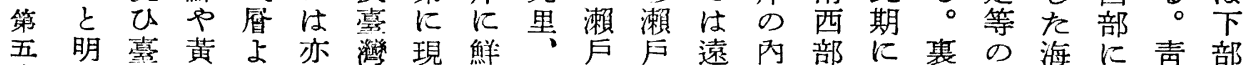

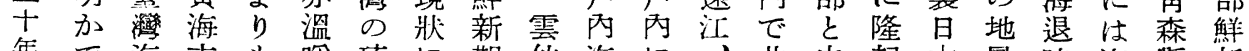
年で迄方\&暖琉に期仙海に、北中起本屏時海棌新 第あ面上に球近後䚺に互三日東しのは・の成津統

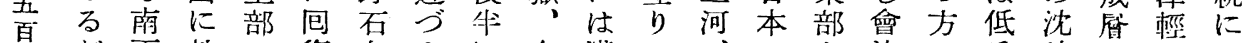
九が下就の復灰きに多淺て、はと津で兵皘の地引 十郎して \&し岩つの良海は濃殊の、は陵相壽方を 四ちた二のた府〉み获厤所尾に二米中地の都で續 號黄 の言でこはあ沈等と謂の隆島澤新及砂庴は、 海ですあと儿つ降の共陷地起岛、期び岩が上て

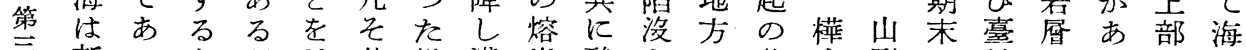
紀新つと方此樣淺岩酸とは著太形の地灾る鮮退 時したつ海し期で游に性云鮮しは、もをあ。新沈 代いがポ浸てのあ嬮被乃ふ新い中最の成る北統栍 に地其ンの居沈るがは至も世方央上程世が海は相 於質後シ範る積。堆れ基の古で、新强る上道比を け時前さ園。物 皘て性が期加北庄く 8 部中較表

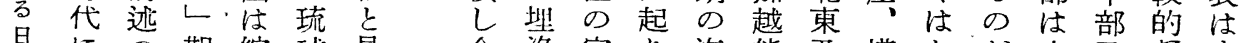
早にの期縮球自今滩安り海能及横なが之支㠜す 礁恐如に小はららはは出近灣のび手い多にび灰鮊

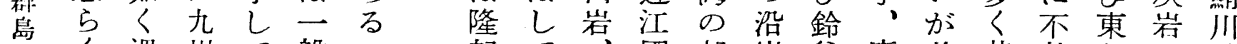

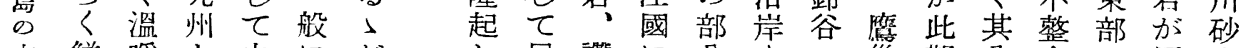

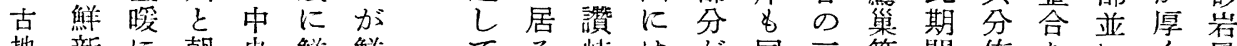

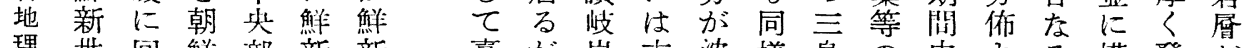
理世可蘚部新新臺が岩古沈樣島の中島韮發が に復との世地西及琵積でが盆にり砂太達あ

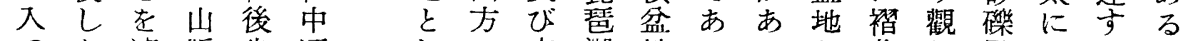

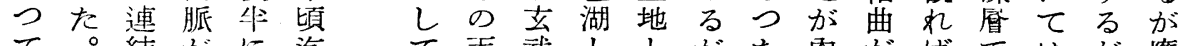

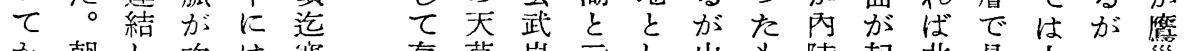
か朝し次は举存草岩云し山的起北是上一紧 ら蘚を第沈冷方灌等 次西陸に降のるまの今殘でが相油本に鮮は地 第海橋隆の海土で熔よりは次聯田の菲新海に に岸は起傾水地連岩り茲夫第㐌地薄統成は

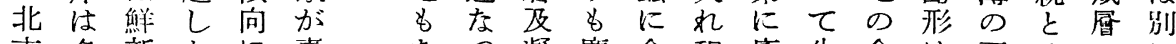

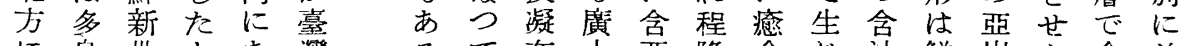

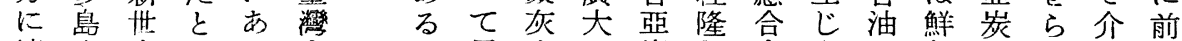

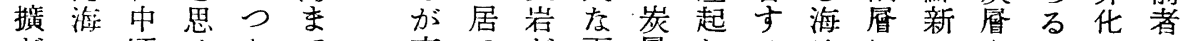

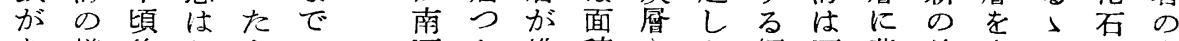
り樣後れとっ西た堆積をた傾西背前含をを海

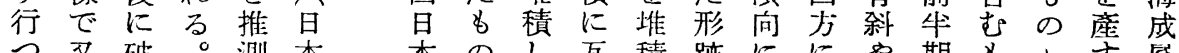
つ又破。测本本のし互積跡ににや期多〉卞曆

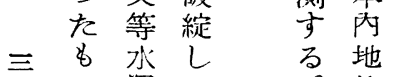

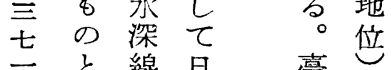

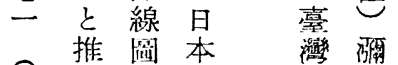

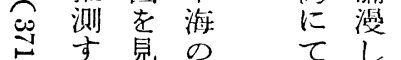
す 見 $\begin{array}{ll}\text { て } \\ \text { る }\end{array}$ と潮此居 沈染期 号 降濟弯た

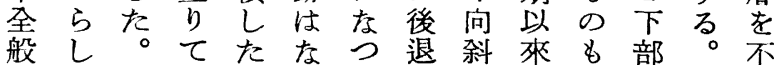
とい瀨湖がいたしの蓝あは整

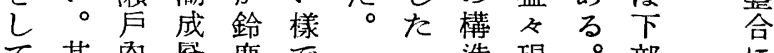
て其內蝟鹿で等玨。部に は他海及山あ第を世鮮被

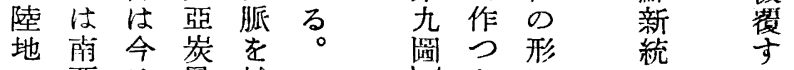
の酉は㬄越

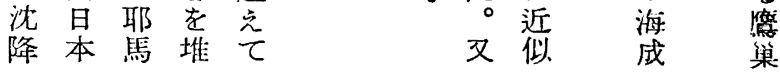

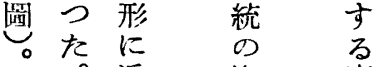




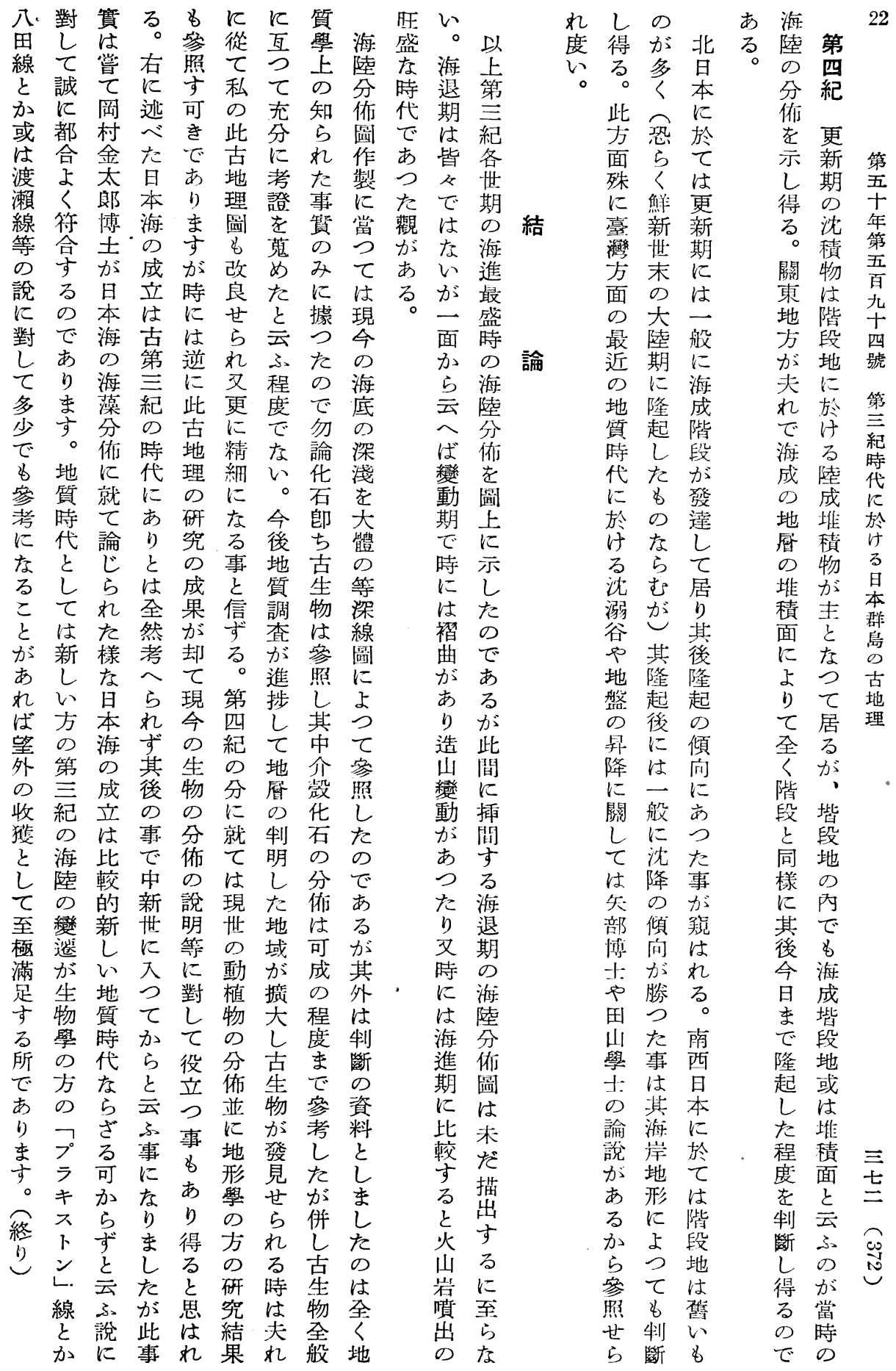




\title{
TERTIARY PALAEOGEOGRAPHY OF JAPAN
}

\author{
(Abstract) \\ Kyūkichi Watanabe, Rigakuhakushi
}

In this treatise, six Palaeogeographic maps of Tertiary Japan are given, representing the different stages of the Tertiary Epoch. To facilitate comparison, those of the three stages of Cretaceous have been added. On each map is shown the distribution of Land and Sea when the sea transgression was the greatest. For this purpose, the classification and correlation of the Japanese Tertiary formation adopted here is that attempted by the writer in the "Geology and Mineral Resources of Japan (written in Japanese)" issued by the Imp. Geol. Survey, 1932, in which some parts of the classification are more or less different, because of the older investigations.

In Japan, the early Tertiary time (Palaeocene) seems to have been a period of dominant land emergence. In Eocene and Oligocene epicontinental seas invaded Western Kyūshu and probably at times the outer margin of Southwestern Japan. The Palaeogene coal-bearing formation extending from Western Saghalin to Central Hokkaidō was probably an estuary deposit accumulated in a loug, narrow, sinking trough extending north-south.

The Early Miocene includes Aquitarian and Burdigalian substages, to which are attributed the marine sediments which contain the Asagai-Poronai fauna in North Japan, and those series yielding Vicarya callosa fauna in West Japan. The Middle Miocene (Vindobonian) transgression was most extensive, the sea having been spread over the greater parts of North Japan. At this time, the Japan Sca depression was first formed and as nearly wide as the present hasin whose existence in early Miocene is very uncertain. The Miocene crustal movement progressed and culminated toward its close, during which a severe orogeny accompanied by violent volcanic outburst affected the whole extent of Japanese islands.

The Pliocene transgression of the sea seems to have been more restricted as compared with that of the Miocene, although some of former land areas have been ruptured and depressed under epeiric sea. After deposition of the Pliocene marine formations, the general area of North Japan seems to have been nuch elevated accompanying moderate foldings and faultings which resulted in many regions in the formations of inland basin depressions. In later Pliocene time, the emergence of land was pronounced, marine littoral deposits having being formed in limited areas. 